Portland State University

PDXScholar

Summer 10-7-2014

\title{
Dialogue in Identity-Based Conflict (Study of Intergroup-Dialogue with University Students)
}

Lisha Shrestha

Portland State University

Follow this and additional works at: https://pdxscholar.library.pdx.edu/open_access_etds

Part of the Gender, Race, Sexuality, and Ethnicity in Communication Commons, and the Interpersonal and Small Group Communication Commons

Let us know how access to this document benefits you.

\section{Recommended Citation}

Shrestha, Lisha, "Dialogue in Identity-Based Conflict (Study of Intergroup-Dialogue with University Students)" (2014). Dissertations and Theses. Paper 2012.

https://doi.org/10.15760/etd.2011

This Thesis is brought to you for free and open access. It has been accepted for inclusion in Dissertations and Theses by an authorized administrator of PDXScholar. Please contact us if we can make this document more accessible: pdxscholar@pdx.edu. 


\title{
Dialogue in Identity-Based Conflict
}

(Study on Intergroup-Dialogue with University Students)

by

Lisha Shrestha

A thesis submitted in partial fulfillment of the requirements for the degree of

\author{
Master of Arts \\ in \\ Conflict Resolution
}

Thesis Committee:

Barbara Tint, Chair

Rachel Cunliffe

Vandy Kanyako

Portland State University 2014 
(C) 2014 Lisha Shrestha 


\begin{abstract}
An individual's struggle with "self," which consists of personal identity and social identity, can create both intra- and interpersonal conflict. In this study, I explored how such struggles inform identity-based conflict and how such conflicts are addressed by intergroup dialogue. A dialogue was conducted with University students, consisting of discussions about participants' struggles with "self" and social identity. These conversations were analyzed using a mixed methods and content analysis approach. The study revealed that identities such as gender play significant roles in creating conflict within "self" and with others. National origin, race, and ethnicity also affect personal identity; however, these identities have greater influence on participants' relationships with others. Four different stages of dialogue were crucial in determining changes in the perceptions of participants. It was learned that dialogue helped participants to give new meaning to their identities. Individual "self”- personal identity—defines each person's ability to understand others, not the social identity. Participants reported their level of trust, openness, and willingness to engage with people not from their own identity group increased and improved because of their participation in the dialogue. Therefore, dialogue can be a valuable tool to understand and transform identity-based conflicts.
\end{abstract}




\section{Acknowledgements}

This study is the culmination of two and half years of work in intergroup dialogue and a product of a process to which many people have contributed.

First, I would like to thank my advisor Dr. Barbara Tint for her guidance, which was crucial for me to keep my focus. I would also like to thank Dr. Rachel Cunliffe, who not only helped to formulate my methods, but was also a constant inspiration. Dr. Vandy Kanyako deserves credit for joining the committee late and for providing his valuable feedback to expand the scope of the current work.

I would like to thank Jill Townley, Associate Director at International Student Life Office and Tia Marie Gomez who helped to organize the dialogue, as well as Surya Joshi, my fellow classmate, for helping design the curriculum and co-facilitating the dialogue. I cannot forget all the participants, whose participation was key for the outputs of this research.

In addition, I would like to acknowledge Stephenie Jahnke, Program Administrator at Conflict Resolution Graduate Program who constantly encouraged me when I needed it. Also, I would like to thank Crystal Ashton, work supervisor at Immigrants and Refugee Community Organization (IRCO) for being supportive and flexible. 
I am also thankful to the Jubitz Family Foundation for generously providing me the graduate assistantship that made it possible to join the Conflict Resolution Program.

At last, I would like to thank my family members, who have been a constant inspiration for me even though I am far from them. 


\section{Table of Contents}

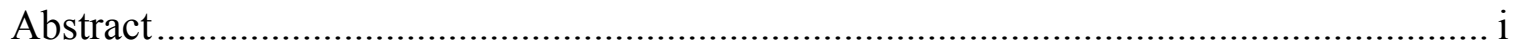

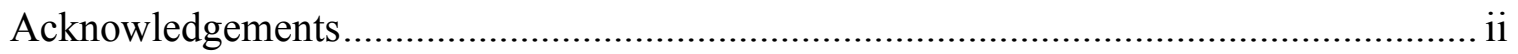

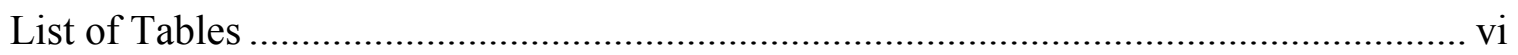

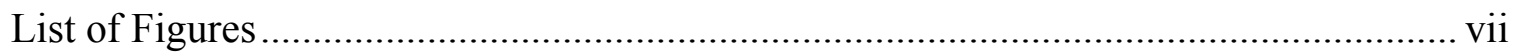

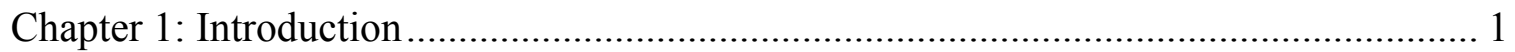

Statement of the Problem..................................................................................... 2

Purpose of the Study and Research Questions.......................................................... 3

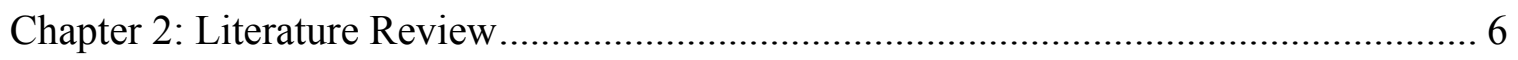

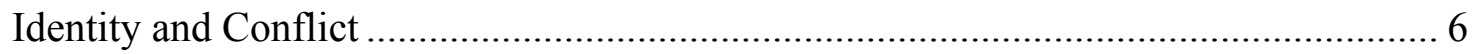

Dialogue in Identity-Based Conflict .................................................................... 8

Intergroup Dialogue in Higher Education.............................................................. 15

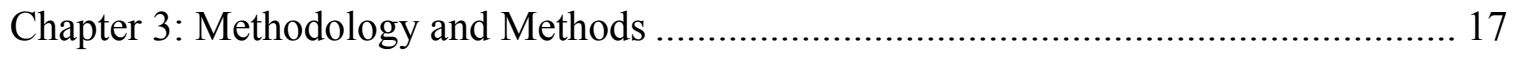

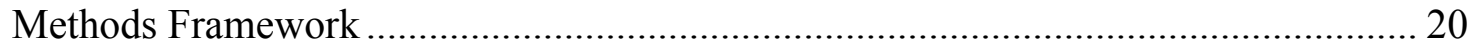

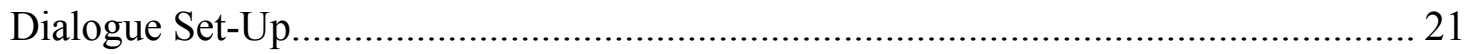

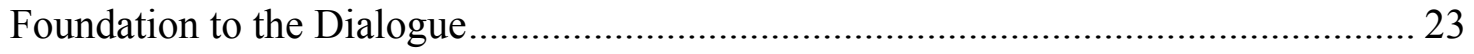

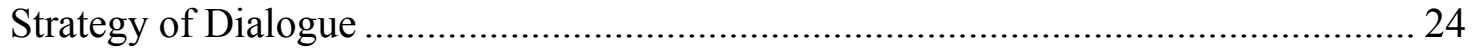

Qualitative Analysis (Descriptive Statistics and Content Analysis) ......................... 25

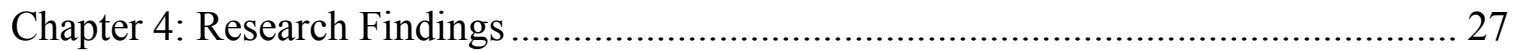

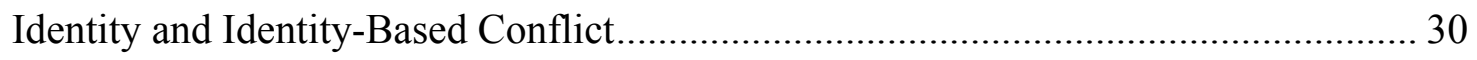

Perceptions of Identity and Identity Conflict....................................................... 36

Chapter 5: Analysis, Recommendations, and Conclusions ...................................... 40

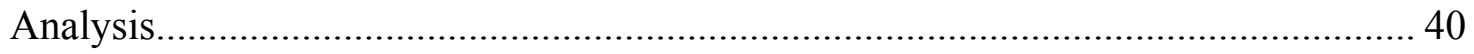

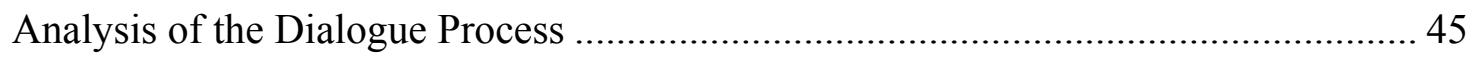

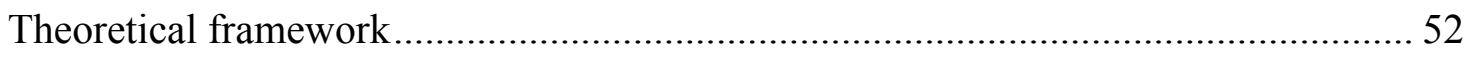

Emerging Questions for Further Research............................................................ 54 


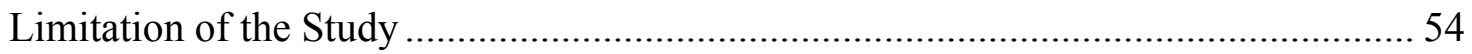

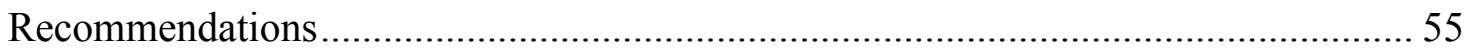

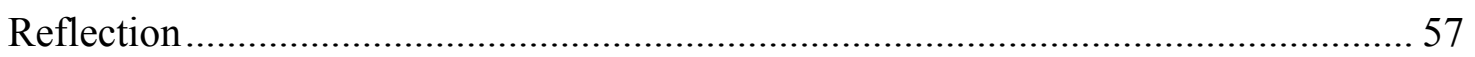

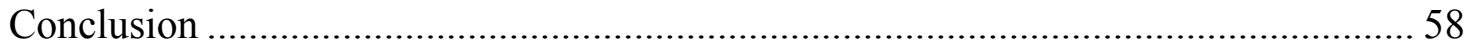

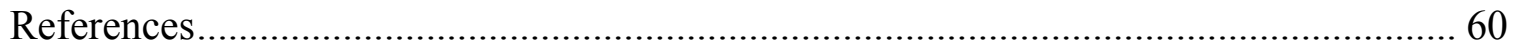

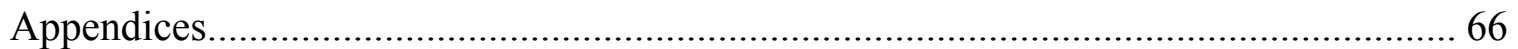

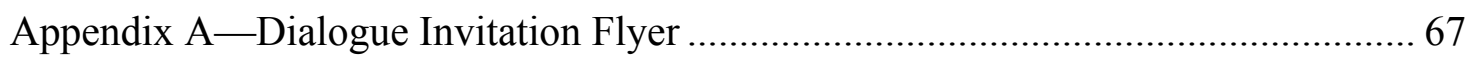

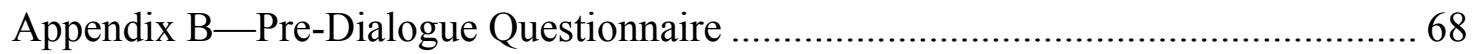

Appendix C_Post-Dialogue Questionnaire .......................................................... 72

Appendix D_-Outline/content of each dialogue session ......................................... 76

Appendix E - Common Group Guidelines (Processed Agreements)......................... 85

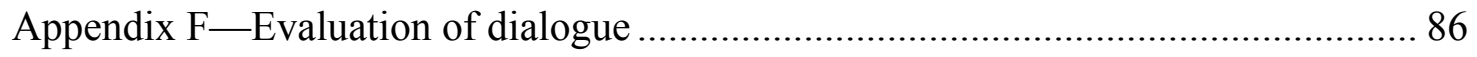

Appendix $\mathrm{G}$ - List of activities used in dialogue process..................................... 87

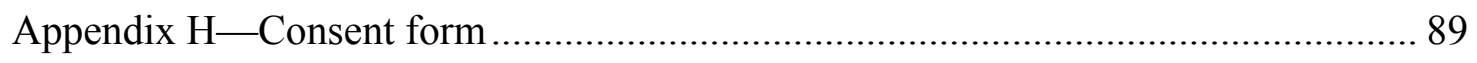




\section{List of Tables}

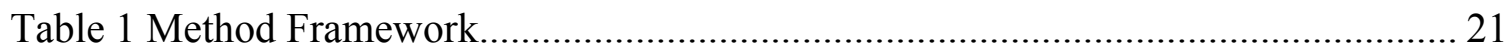

Table 2 Characteristics of the Participants................................................................ 27 


\section{List of Figures}

Figure 1 Participants affiliation to social identity groups.......................... 30

Figure 2 Partcipants' responses to identity-based conflict......................... 31

Figure 3 Participants' responses to fear, prejudice, and discrimination.................35

Figure 4 Participants' changes in perception...................................... 38

Figure 5 Theoretical Framework................................................... 


\section{Chapter 1: Introduction}

Societies consist of individuals with different identities, and when people fail to understand identities different from their own, conflict can occur. Gurevitch (1989) stated that people who attempt to establish conversation with people with different identities tend to ignore the "otherness" and dissimilarities between them, focusing instead on mutual understanding, sameness, and commonality. This tendency can complicate the process of creating mutual understanding and accepting differences. The process of dialogue can create an environment where dissimilarities between different identities are observed, discussed, and acknowledged. This distinctive approach to discourse across conflicting identities is known as intergroup dialogue (Gurin, Peng, Lopez, \& Nagda, 1999). Intergroup dialogue creates new opportunities for understanding one's inner self as well as the identities of others.

People with diverse cultural and language backgrounds interact with one another on a day-to-day basis in a higher education system. In such a social setting, there are frequent opportunities for stereotyping, judgment, prejudice, misunderstanding, and miscommunication, which can ultimately become a socio-psychological problem for an individual, group, or community (Zuniga, Nagda, Chesler, \& Walker, 2007).

Intergroup dialogue with university students on the topic of identity and identity conflict is the main focus of this study. In this study, I question and analyze different aspects of identity and its role in shaping one's inner self in relation with others. Various researchers (Schoem \& Hurtado, 2001; Zuniga \& Meyers, 1995; Zuniga, Nagda, Chesler, \& Walker, 2007) suggest that intergroup dialogue prepares students to face broader issues of diversity in their academic and professional lives. Intergroup dialogue has been 
widely used to address identity-based issues that occur in students' interactions in university settings and has also been taught as a course in many contexts.

In this study, I further explore how an intergroup dialogue affects the perception of students when dealing with their internal conflicts and interpersonal conflicts outside of the university setting. I analyze whether stereotypes, judgments, and prejudices are outcomes of identity-based conflict and how stereotyping, prejudices, and judgments inform identity-based conflict.

Differences and conflicts were discussed in a series of dialogues with students from Portland State University (PSU), consisting of one 2-hour session per week for five weeks. Students were provided a safe space to share their experience through a facilitated dialogue. The dialogue followed a guided outline for each session. The study analyzes the personal stories and experiences of the student participants and provides insight into identity-based conflict. The findings illuminate changes in perception and observed effects on the dialogue process through the shared stories and experiences.

\section{Statement of the Problem}

Forester (1999) explained that values are deeper than simply personal or group interests and are strongly connected with identity. Therefore, struggles of an individual in choosing between values and interests can create both intra- and interpersonal conflict. Further, a person's uncertainty in determining his or her identity might create differences during interactions with others. In the university setting, the conflict can be even more complex. University students not only face stereotyping, racial profiling, bias, and academic pressure but also deal with their internal and external (personal and interpersonal) conflicts. These conflicts can be the result of their inability to cope with 
identity-based prejudices, or due to their inability to understand their own identities. Allport's (1954) psychodynamic and phenomenological processes emphasis on human aspects of prejudice revealed prejudices that arise because of a person's own internal thinking and how she or he views the outer world.

In this study, I attempt to find existing identity-based conflict in students' lives. Identifying and exploring these conflicts should reveal how conflict affects each student as a person, as well as how it influences relations with others. In addition, I explore how these students want their identities to be presented and what role each person's identity plays in dealing with existing identity-based conflicts.

\section{Purpose of the Study and Research Questions}

The purpose of this study was to explore and examine the nature of identity-based conflict in the lives of students at Portland State University, using a mixed methods approach. The main objective of the study was to explore identity-based conflict in the participants' lives. In addition, I sought to examine the effects of intergroup dialogue in perceiving identity conflict. Finally, it was important to understand the roles played by gender, race, ethnicity, and class during the dialogue process. With these objectives in mind, the following research questions were developed to guide the study:

1. How does identity inform conflict among students in a university setting?

2. How can dialogue be used to address identity-based conflict among students in a university setting?

Interviews conducted with several PSU student groups and institutions revealed that students engage in meetings and reflection sessions; however, there are no programs 
to engage them in deeper conversation on issues of identity (S. R. Joshi ${ }^{1}$, personal communication, September 4, 2013). Therefore, this study could be an asset to university students, academicians, and researchers who plan to conduct similar dialogue projects in other PSU program settings. The results of this dialogue research may be helpful for those who need guidance in preparing a dialogue curriculum. It may be a useful guide to implementing a dialogue series to help students explore each other's identity issues.

After participating in this study, I anticipate participants will have a better understanding of their own identities, as well as the values of others.

Various intergroup dialogues have been conducted in different colleges and university to foster better understanding and improve level of engagement among the students (Kuh, Kinzie, Schuh, Whitt \& Associates, 2005). Intergroup dialogue has its roots in higher education; the process is well grounded in theory, knowledge, research, and pedagogical principles drawn from the scholarship of teaching and learning (Nagda \& Gurin, 2007). However, Wayne (2008) reported a lack of research designed to explore the effectiveness of dialogue processes. Many academic and nonacademic exchanges of ideas and interaction take place in a university setting, where students, instructors, and employers come from different identity groups with wide differences in personal identity and "self." Social situations such as this university setting are organic communication environments, likely to create misconception and misunderstanding, which can lead to assumptions, stereotyping, biases, and conflict. Thus, a university setting is a suitable

\footnotetext{
${ }^{1}$ Surya Raj Joshi is a colleague at Conflict Resolution Program, Portland State University. I collaborated with him to create a dialogue curriculum. He is also the co-facilitator of dialogue. Hereafter, he will be referred to as a colleague.
} 
place to conduct intergroup dialogue with students who exhibit a wide range of personal and social identities. 


\section{Chapter 2: Literature Review}

This section of the chapter provides a description of linkages between theories and contemporary research on identity, conflict, and intergroup dialogue. First, the chapter outlines why identity and conflict between people coexist with their propensity toward nonconformity. Second, I discuss how such coexistence and need for nonconformity are confronted and resolved. This leads to exploration on dialogue as an important method to aid observations of confrontation and resolution in an identity-based conflict. The final part of this chapter reflects the importance of intergroup dialogue in higher education.

\section{Identity and Conflict}

The role of identity cannot be ignored while considering intrapersonal, interpersonal, or intergroup conflict. Struggle between personal and social identity can create intrapersonal or interpersonal conflict (Adams \& Marshall, 1996). This section of the chapter focuses on identity based on personal value systems, known as personal identity, and the identity given by society, called social identity. The concept of "self" reported by various theorists such as Allport (1955), Cooley (1902), and Epstein (1973) form the basis for a discussion of how the concept of self affects an individual when he or she is driven by social norms and social affiliations. In this section, I review possible connections between personal and social identity and describe how interactions between "self" and social identity create conflict. In a social context, humans tend to mirror themselves through the lenses of others. Sometimes mirroring self-image through others or through different social norms can be damaging. People may struggle to choose the identity to which they most closely align and by which they would like to be identified. 
For example, an individual thinks of his or her own "self" as a collection of desires for physical, material, and psychological needs and accomplishments. All of his or her behaviors are guided by the desire to satisfy the "self."

Allport's (1955) theory on proprium with regard to self refers to "all the regions we regard as intimately and essentially ours" (p. 13). This describes those aspects of an individual that he or she considers important, has control over, and that can be used to enhance the self. These thoughts form the essence of an individual's self-concept, attitudes, and beliefs (Allport, 1955). The proprium theory shapes the idea of a person's self-identity in the outer world. The way a person thinks of "self" is based on who he or she is, which determines his or her ability to understand the outside world and helps to develop his or her personal identity, or the self that reflects his or her true being.

The concept of a looking glass self(Cooley, 1902) refers to an individual's ability to perceive him- or herself in the way that others perceive him or her. This concept is different from the concept of proprium to self. In the theory of proprium to self, an individual is aware of how others think of him or her and guided to do those things accepted and approved by others in the society. Accepting things that he or she does not value sometimes threatens the "self" of an individual. For example, a married woman in Hindu traditional society often wears a symbol to indicate she is married. This practice is guided by how she is perceived by her family members, relatives, and society. However, her "self" may be reluctant to wear a symbol of marriage. The difference between how she thinks and how her behavior changes because of society creates conflict within her "self." Thus, there may be a constant struggle between the personal identity and social identity, which may lead to confusion and conflict. Sen (2009) states, "Personal and 
social identity are two different concepts and the idea of putting them together raises serious question of coherence" (p.285). Sen (2009) further states that personal identity demands the "sameness" of a person, whereas social identity focuses on identifying ourselves with others based on social affiliations, religion, and nationalities.

People can indulge in their personal identity and completely dismiss their social affiliations and social identity. This can affect their relationships with others. Finding harmony between personal and social identity can be difficult, as each person carries multiple identities at different times and in different situations. Considering again the example of the Hindu woman, her identity is torn between her individual values and her society's social norms and beliefs. If she listens to her values, she creates a conflict with her family members; if she listens to the family and social values, she creates conflict within herself.

\section{Dialogue in Identity-Based Conflict}

Many researchers have defined dialogue as a face-to-face conversation facilitated by trained dialogue practitioners, intended to build relationships between members of different social identity groups (Schoem \& Hurtado, 2001; Stephan \& Stephan, 2001; Wayne, 2008; Zúñiga, Nagda, \& Sevig, 2002). Referring again to Allport’s (1955) proprium to self as a factor that helps an individual align to a particular group " $\mathrm{X}$ " where he or she shares similar values and ideologies and feels more comfortable, secure, and trusted, then we can say that this person belongs to group "X." Allport (1954) refers this group alignment process as an ingroup phenomenon. Various researchers have found that the "self" of the individual feels connected with other members' in the ingroup. $\mathrm{He}$ or she may think this group favors his or her ideas. Having an ingroup connection helps 
him or her maintain high self-esteem (Fisher, 2000; Gurin, Peng, Lopez, \& Nagda, 1999; Stephan \& Stephan, 2001; Taylor \& Moghaddam, 1994; Wayne, 2008). The individual in the ingroup interacts with groups of people who display different views and behaviors, and considers the members of the different group as an outgroup. Thus, the choices a person makes regarding membership in a group come from his or her "self."

When members of ingroup and outgroup come together, acceptance of the other group can be challenged, and the dynamics of these relationships may change or remain constant depending on the situation. Sometimes hostility toward the outgroup, or toward an individual in the outgroup, is high (discrimination, hate, physical, or verbal abuse); sometimes hostility is mild, presenting as rejection or avoidance (Fisher, 2000; Stephan \& Stephan, 2001). The struggles between ingroup and outgroup members result from different beliefs and value systems. As a group, members carry a distinct social identity and perceive the other group as a threat to their group identity. This type of conflict causes a community or a social group to increase hate and prejudice toward the other group. Unanswered questions include the possibility that conflict or struggles only exist between ingroup and outgroup members. However, there may be struggles between ingroup members, where members find their personal values colliding with values of the group. It is possible that dialogue can help to understand these aspects of ingroup and outgroup conflict.

Researchers have theorized that when members of different groups come together in a safe space with an intention to improve their relationship and understand each other, a positive interaction is the result. Allport (1954) and Pettigrew (1998) referred to this theory as the contact hypothesis. Intergroup contact is a source of mutual acceptance and 
helps reduce prejudice toward others (Allport, 1954; Pettigrew \& Tropp, 2005). Thus, a "sustained communication" (Zuniga, Nagda, \& Sevig, 2002, p.8) through skilled facilitation in a safe space helps to minimize such challenges and barriers. Such interaction can sometimes help to reduce stress and confusion, although the absence of skilled facilitation can sometimes negatively affect the interaction. Dialogue is a process to create a space where people listen deeply enough to understand and learn to practice genuine respect and empathy toward one another (Saunders, 1999). Such deep conversation not only creates awareness in helping participants find an individual self, but also eases the process of discovering how he or she is perceived by others. This conversational discourse helps to minimize misconceptions toward others and creates deeper internalization and acceptance of change within the "self."

Dialogue is a unique approach in dealing with conflict. The uniqueness is created by different stages of dialogue. The appeal of dialogue is that it allows people to feel vulnerable without losing their identity and yet respects the emotion shared within the group. There are many approaches to dialogue. Some of the dialogues are more structured; some are not. Some are detail- and process-oriented from the start, while some are organic in nature.

Various researchers have presented different approaches to dialogue. Cayer's (2005) analysis of Bohm's dialogue referred to five different dimensions of dialogue. The five dimensions include dialogue as a conversation, inquiry, creation, participation, and collective mediation. Bohm (1991) claimed dialogue is a way to explore the roots of crises and difficulties. Dialogue helps participants inquire into and understand causes of obstacles interfering with communication. An individual in a dialogue thinks collectively 
and observes things from different dimensions, not only the "self." The hidden internal values and intentions sometimes control an individual's behavior and actions without allowing him or her to realize what impact has already occurred as a result of his or her thought process (Bohm, 1991). Therefore, the dialogue helps to explore those aspects of human thoughts that represent hidden values and intention, allowing the person to find the real meaning and intention behind what prompted him or her to think and behave in a certain way. This idea connects with Allport's (1954) statement on proprium to self. Some individuals think in a way that makes them believe that whatever they are thinking or doing is correct, providing moral support to stand out in front of others. While doing so, however, he or she fails to anticipate the consequences of his or her actions, which represent the result of the thought process. Allport refers to this as a behavior of opportunistic functioning. Some individuals may act differently despite what they feel inside to avoid fear, guilt, and shame from other people or social groups. This is an example of Cooley's (1902) looking glass self, where an individual mirrors his or her own image through the lens of others. When both of these phenomena-opportunistic functioning and looking glass self-occur simultaneously in a situation, confusion may result as the person attempts to determine which group he or she belongs to and what value systems he or she should follow.

One of the most important aspects of dialogue is to understand the dynamics of "self" and the awareness that comes with suspending one's thoughts. Bohm (1991) emphasized thoughts and suspension of thoughts to generate self-awareness not only of the conscious intellect but also feelings, emotions, intentions, and desires. Thought influences actions; often without the thinker realizing what actually occurred during the 
process of his or her actions (Bohm, 1991). In addition, dialogue is a powerful means of understanding how our thoughts function (Bohm, 1991). Dialogue also helps to explore why, when, and how thoughts become action and offers an opportunity to check if such action and thoughts are a result of proprium to self or looking glass self.

Bohm (1991) stated that an evaluation on how our thought functions helps in the reflecting or mirroring back of thoughts. This mirroring slows down the thought process, allowing an individual to revisit the upcoming action and possible consequences. The word dialogue derives from two roots_-"dia," which means "through" and "logos," meaning "the words." Thus, in a dialogic situation, thoughts become words and words become action after reflection and evaluation of the origins and consequences of thoughts. Dialogue processes also allow reflection on the source of the thoughts. It is helpful to evaluate whether the thought process is coming from proprium to self or looking glass self. In other words, an individual must choose between protecting and following his or her personal identity and protecting and following his or her social identity. People often struggle between these two identities. The inherent dissonance in choosing two different identities can inspire criticism of others who are not viewed as a part of the ingroup. Therefore, dialogue as a transformative process allows an individual to suspend judgments, inquire deeply to internalize change, and creative new meanings of thoughts and action.

Senge (1990) referred to Bohm's (1991) dialogue research in his writings and developed stages of dialogue and practice for organizational development. Senge's view on Bohm's dialogue emphasized three major processes: 
1. All participants must "suspend" their assumptions, literally to hold them "as if suspended";

2. All participants must regard one another as colleagues;

3. There must be a "facilitator" who "holds the context" of dialogue" (p. 243)

Senge's work on dialogue has been used extensively in the field of leadership and organizational development. In addition to its use in organizational settings, the conception of dialogue as encompassing different stages has been valuable in academic, social, and political settings. The four stages of Senge's framework for dialogue (Senge, et al 1994, p. 363) are:

1. Instability of the container

2. Instability in the container

3. Inquiry in the container

4. Creativity in the container

This conceptualization of the dialogue process has contributed new steps to Bohm's (1991) theory. In Senge's dialogue model, the process before the inquiry is critical. Dialogue cannot be forced; respecting and listening to one another does not happen in the first stage (Senge et al., 1994). Therefore, the first stage of dialogue, instability of the container is critical to bring together people with unexpressed desires, prejudices, and differences in opinions. Senge states that at this stage "dialogue confronts its first crisis" (p. 363). In this stage, participants feel like they are in an absurd situation where they are constantly being observed and observing others. As an observer and as a person being observed, an individual might think about how others perceive him or her. The person may wonder if his or her personal identity is being scrutinized or if 
the situation is threatening. Here, the person thinks more of the looking glass self rather than how he or she wants to behave or act. In this stage, the person is not willing to reveal the "self," as he or she cares more about protecting his or her personal identity. At this moment, he or she does not feel bothered about a social identity or any other social affiliation. The individual thinks about his or her "self." Why does an individual think more of his "self" and personal identity in this first stage of dialogue? The answer maybe because the environment is new or may not feel safe or trustworthy, making the person feel vulnerable and disinclined to disclose the "self."

The other three stages of dialogue somewhat resemble Bohm's (1994) approach to dialogue. The second, instability in the container focuses on participants learning to accept the differences and suspend judgments and assumption. They feel awkwardness, uneasiness, and fear in this stage. However, they gradually learn to reflect and listen for the reasons that have brought them together. During this stage, participants learn to explore the meaning and purpose of this "togetherness."

Participants' levels of awareness increase as they have greater insight into their situation in the third stage, inquiry in the container. Participants are encouraged by such insights to share their personal stories and experiences. This sharing can intensify the momentum of dialogue and can create another form of crisis if the sensitivity and intense emotions are not addressed. The energy from the group can be transferred and distributed within the group to develop new and positive insights. The final stage of dialogue, creativity in the container, shows participants internalizing and accepting the changes within their "selves." This is the phase where individuals may experience transcendence. 
Both Senge's and Bohm's approaches to dialogue specifically reference to the suspension of thoughts. Both researchers have extensively elaborated on its importance in dialogue. Bohm expressed skepticism about using dialogue in an organization setting because of the prevalence of hierarchy among participants. Senge (1994), in contrast, viewed dialogue as possible even when participants come from different hierarchies if participants are willing to give up their privileges and surrender their power and fear. $\mathrm{He}$ further mentioned that participants can overcome risk mutually and establish a sense of safety if they treat one another as colleagues.

Bohm (1991) synthesized two important aspects of dialogue. The first aspect is the systems or holistic view of nature and the interactions between thinking and internal "models." The second aspect is our perceptions and actions. Senge adapted Bohm's method of dialogue by adding one step, involving noticing the "crisis" and processing the crisis before inquiry.

\section{Intergroup Dialogue in Higher Education}

Intergroup dialogue in higher education is being developed as a revolutionary approach to foster understanding of cross-cultural differences within academic institutions (Zuniga et al., 2007). It is an innovative approach designed to build cohesion among students from a variety of backgrounds. Nagda and Gurin (2007) referred to intergroup dialogue as a path-breaking approach in higher education that promotes student engagement across cutural and social divides, fosters learning about social diversity and inequalities, and cultivates an ethos of social responsibility. The University of Michigan-Ann Arbor first initiated intergroup dialogue during the 1980s to address rising racial conflict (Zuniga et al. 2007). The process has now become popular with 
different colleges and universities in the United States (p.3). Intergroup dialogue

programs are currently operating at a number of institutions, including Arizona State

University, Bucknell University, Portland Community College, Syracuse University,

University of Michigan, University of California, and University of Washington (Schoem

$\&$ Hurtado, 2001). Clearly, the influence of intergroup dialogue has become widespread

during the last three decades. This wide acceptance of intergroup dialogue is based on its

effectiveness to address many of the current student communication challenges found at

higher education institutions.

In addition to training in facilitated dialogue, many institutions have accepted

dialogue as an academic course. Lopez and Zuniga (2010) mentioned that

Dialogue represents an important approach for preparing students for multicultural democracy because it challenges [them] to grasp the significance of social identities and exercises critical imagination in understanding and taking action with others. Students can learn and build their capacity not only by understanding different perspectives but also by working collaboratively towards social change and justice. It also helps to develop broader moral value to embraces uniqueness of diverse socio-political reality. (p. 35)

As an academic course, intergroup dialogue exposes students to the theories underpinning the dialogue process. Usually, facilitators follow a structured curriculum to conduct the dialogue. Facilitators are carefully selected, prepared, and mentored (Schoem \& Hurtado, 2001; Zuniga et al., 2007). Students are given assignments or a collaborative group project based on the need and nature of the dialogue. Intergroup dialogue benefits students and strengthens university-community connections (Lopez \& Zuniga, 2010). This societal connection is important for universities and institutions as they play a significant role in influencing local business, politics, and social life. 


\section{Chapter 3: Methodology and Methods}

In this study, I combined quantitative and qualitative methodologies to undertake the research. A method framework was designed to conduct the dialogues and analyze the results (see Table 1). This framework was based on a review of research methods appropriate for the dialogue process and analysis. Qualitative data collection (consisting of dialogues and pre- and post-dialogue qualitative questions) was bracketed by two phases of quantitative data collection (pre- and post-dialogue questionnaires), which were used to provide descriptive statistics to validate the analysis of the dialogue data. The dialogue was a conversation between the participants on the broad topic of identity and related issues. The views shared during the dialogue were based on the participants' personal experiences, observations, and interactions with different people in various contexts. These conversations were recorded and videotaped with each participant's consent.

Content Analysis (CA) was used to analyze the actual dialogue process. Various researchers have defined $\mathrm{CA}$ as a systematic, replicable technique for compressing many words of text into fewer content categories based on explicit rules of coding (Berelson, 1952; Krippendorff, 1980; Weber, 1990). However, Holsti (1968) specifically defined CA as "any technique for making inferences by systematically, and objectively identifying special characteristics of messages" (p. 608). During a communication, there can be various instances where certain words are repeated or given importance in a particular context. CA helps to narrow and identify words or text of potential importance. It also allows the researcher to discover and describe the focus of individual, group, institutional, or social attention (Weber, 1990). 
Kohlbacher (2006) explained two different types of CA—classical content analysis and qualitative content analysis. In the classical content analysis approach, analysis is done by counting the numbers of occurrence of words per text or unit, focusing more on quantitative aspects of data. It is also defined as "the process of studying recorded human communications" (Babbie, 2001, p. 304). However, Kracaucer (1952) argued that the classical approach of quantitative orientation neglected the particular text quality of texts or units. He further mentioned that data analysis is not only "counting" or measuring patterns in the texts or units but also a potential interpretation of text or communication. Supporting his idea, Ritsert (1972) pointed out that the classical approach does not focus on the context of text components, latent structures of sense, distinctive individual cases, and things that do not appear in dialogue (p.39).

Qualitative content analysis focuses on recorded communication, i.e., transcripts of interviews/discussions, protocols of observations, videotapes, and written documents (Kohlbacher, 2006). Stemler (2001) explained four different types of defining coding units of data as (a) natural or intuitive borders units, (b) syntactically coding units, (c) referential units, and (d) propositional units. This study used propositional units to define the coding units of the conversation that occurred in the dialogue process. This coding approach helped in breaking down the text or communication in order to examine underlying assumptions (Krippendroff, 1980). Mayring (2002) explained three distinct analytical procedures to analyze data—summary, explication, and structuring. Summary reduces material or data without losing the core content, while explication involves 
explaining, clarifying, and annotating the material. Structuring uses a detailed multistage process to establish a structure according to content, form, and scaling.

Mayring (2002) further explained that units of analysis are determined and dimensions of structuring are established based on theories. These are further processed and extracted, creating definitions and providing key examples. Mayring further explained two approaches to developing a category system to locate appropriate text components: inductive category development and deductive category development. Inductive category development has been used to categorize frequent areas of ideas explored during the dialogic conversation. Mayring (2000) explained inductive category development as,

The main objective of the procedure is to formulate a criterion of definition, theoretical background, and research question, which determines the aspects of textual material taken into account. Following this criterion, the material is worked through and categories are deduced tentatively and step-bystep. Within a feedback loop the categories are revised, eventually reduced to main categories. ( $\mathrm{p} 4$ )

Content analysis in a powerful data reduction technique when used properly and also is replicable technique for compressing many words of text into fewer content categories based on explicit rules of coding (Stemler, 2001). When analyses are done to know the underlying assumptions of views shared then coding views based on the content and situation is crucial. Thus, key aspects of shared in the dialogue were propositioned as a unit of analysis which were summarized, explicated and structured for possible interpretation on data. These data were further categorized and analysed with quantitiatve analysis (e.g. frequencies) and checked for reliability with research questions, objective and literature. 


\section{Methods Framework}

The needs of the study provide the impetus for choosing the content analysis (CA) research method for examining trenda and patterns of the dialogue. Also, the methodology helped in categorization of group of words with similar meanings and connotations shared in the dialogue. CA is a systematic procedure for this study because of its relevance in analyzing textual data from social communications. The inductive category development was chosen for its value in categorizing the important views shared in the dialogue and analysis of the situation in which the conversation orginated or shared. This information was deduced into a category of most shared ideas during the dialogue. This deduced categories were interpreted using theoriectical framework (See Figure 5).

This study uses both qualitative and quantitative methods. The dialogue itself represents the main part of the study; however, the dialogue is supported by pre- and post-dialogue questionnaires, which were used to generate descriptive statistics. Thus, the method consists of several different components, as shown in Table 1. The table has 4 phases consisting of how the dialogue was approached and set, processes to organize dialogue and strategy of inquiry and data analysis techniques. 
Table 1

Method Framework

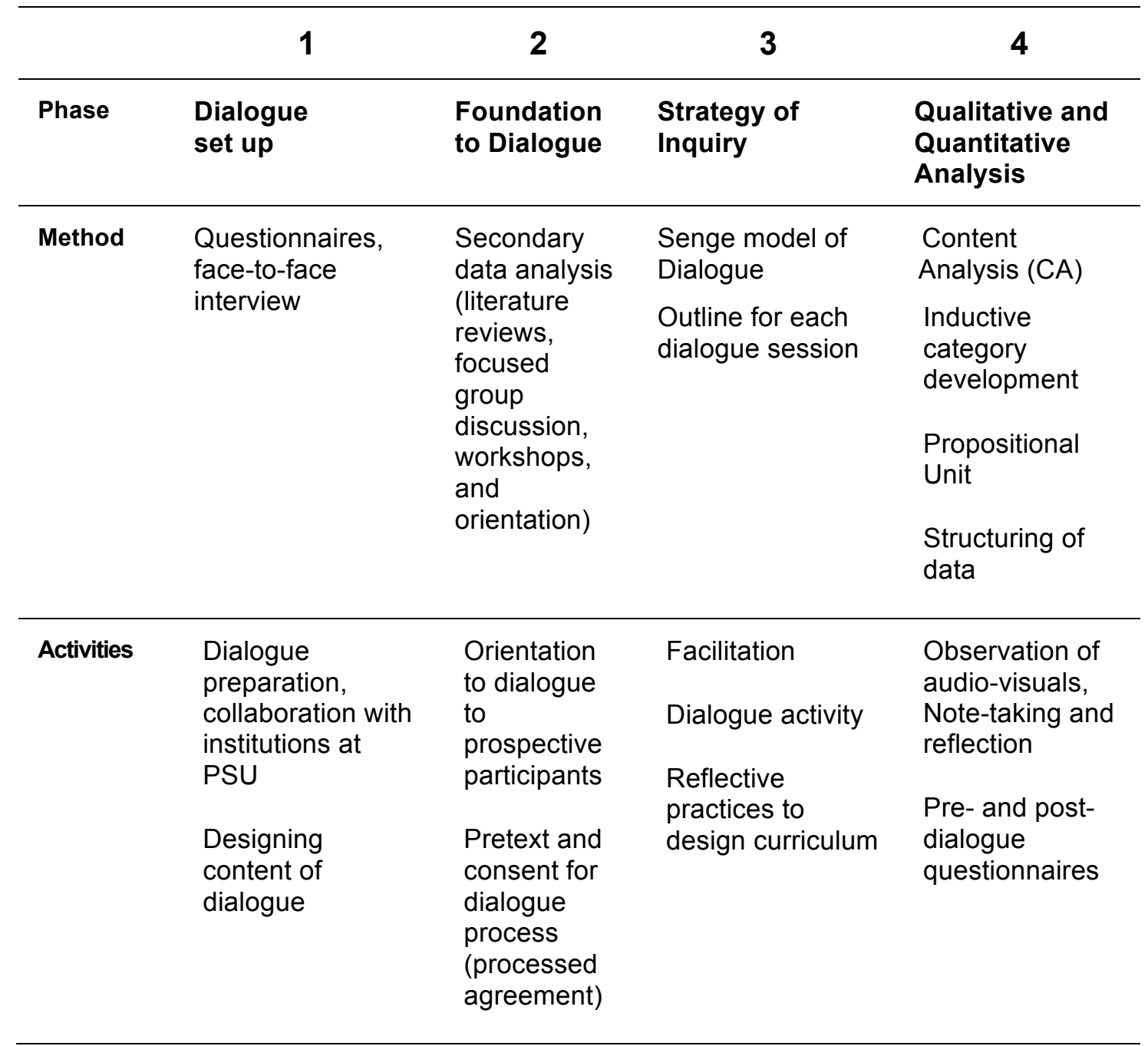

\section{Dialogue Set-Up}

Setting up the dialogue event began with identifying the population from which an appropriate sample could be selected. First, initial outreach of interested partner institutions was done through one-to-one meeting with representatives from the Office of International Studies (OIS). The idea of the dialogues was shared between different institutions. This induced collaboration with different institutions and also brought in 
their perspectives on the necessity of intergroup dialogue at PSU. Additionally they helped me to navigate PSU's student population to recruit interested participants. Collaborating offices OIS and Associated Students of PSU (ASPSU) helped recruit student participants for the dialogue.

The initial meeting for partnership and collaboration with the Office of International Studies at Portland State University occurred in May 2013. A decision was made at the initial meeting on the role of Office of International Studies (OIS) in supporting the dialogue. It was decided that OIS would provide space for dialogue and support for logistics such as certificates to the dialogue participants, refreshments, and a token of appreciation upon successful completion. In preparation, a workshop on empathetic listening skills was given for the International Student Mentor Program (ISMP) students during August and September 2013. The purpose of the workshop was to train possible dialogue participants on good listening skills. The researcher also collaborated with a colleague to prepare dialogue curriculum. The outcome of the empathy listening workshop was useful to build relationships with the students.

The other collaboration was with Associated Students of Portland State University (ASPSU) for possible recruitment of the student participants. An information flyer was distributed in OIS and ASPSU. The flyer was circulated to several staff members, posted on notice boards across the campus, and forwarded through different listserves to reach the largest possible number of PSU students (see Appendix A). OIS also referred some of its students from the International Scholar Program (ISP). Once the students responded to the information through email, an orientation on dialogue was conducted in October and November. 
The dialogue curriculum was developed in consultation with my colleague before and after of each dialogue session. Several other dialogue curricula were studied and different models were analyzed in order to build the dialogue contents (Tint, 2012; Wah, 2004). The process itself was reflective and based on the discourses of previous sessions, observations of the facilitators, and interactions between the facilitators during the dialogue. The curriculum was not solely based on the inquiry or key dialogue questions. The curriculum consisted of different identity-related activities and icebreakers for each session. I served, as one of the two facilitators of each session and Surya Joshi was the other. The activities aligned with an area of interest chosen for each specific dialogue session. Facilitation skills and the different stages of dialgue helped to identify issues. I self-reflected on the events through journaling, consulted with the co-facilitator, and used content analysis approach to further interpret and analyze the findings.

\section{Foundation to the Dialogue}

An orientation was given to the participants who expressed interest in participating in the dialogue. After hearing the basic introduction of the study purpose, participants were asked about their expectations and reasons for their participation. It was clear that most of the participants had multiracial backgrounds. Many asked how dialogue addresses identity issues, while some wanted to improve facilitation skills. Some of the participants were curious about the topic, and some were more interested in learning about the process itself.

The orientation introduced the concept of dialogue through an activity centered on the elements of power and privilege. The purpose of this orientation session was to help participants understand the key elements involved in dialogue and give them a clear 
preview of their possible experience if they chose to participate in the five weeks of dialogue sessions and one session of orientation. Participants were provided with a flow chart diagram of Senge's (1994) four stages of dialogue to evoke understanding of the different stages of dialogue. Out of 13 interested participants, 11 confirmed their willingness to participate in the dialogue. Interested participants were given consent form to sign (see Appendix $\mathrm{H}$ ) and were informed of the date of dialogue. Later, an email was sent to remind participants of scheduled dialogue sessions.

\section{Strategy of Dialogue}

The third stage of the dialogue was the actual dialogue process, where dialectical relationship between participants were observed and used for creating the outline for the next dialogue session. The inquiry method followed Senge et al (1994) four stages of dialogue, which suggests that participants should feel uncertain and vulnerable to the process during the initial stages of the dialogue. In anticipation of this challenge, I created opportunities to develop trust within the situation. The trust between facilitators and participants were crucial in the different stages of dialgogue. The tone of voice, neutrality while inquiring, and reflecting back to the group was the key factors to develop and maintain trust within the group. Mindful listening skills were helpful to absorb the group's energy (emotions and intensity of situational social experience) and reflect it back to an individual or using an individual's energy and reflecting it back to the group. Reflecting energy back to individuals and the group created a vibrant environment and eased intense situations, which ultimately motivated participants to recheck their current presence of mind and emotions. Such reflections also provide evidence of any new consciousness and understanding that may have emerged in the group. 
Observing and detailing the semiotic nuances of participants' emotions, body language, gestures, tone of voice, and frequency of interaction was critical in identifying where the dialogue process was headed and which identity-related topics intensified and triggered participation. These processes were used to shape the dialogue for subsequent sessions. Several inquiries planned for a session could not be asked due to the group's flow of energy on the ongoing topic. I noted such instances, gave respect to the group's thought process, and frequently checked the emotions of less interactive participants. There were many moments of reflective and mindful practice. I also practiced a self-care approach, and checking my emotions during and after each session. Such practices were performed according to the recommendations found in the socio-cognitive approach, in which one analyzes the effect of the semiotic relationship between the participants and the facilitator (van Dijk, 1995). These relationships also influenced the preparation of inquiries and activities for subsequent dialogue sessions.

The first session included preparing a processed agreement (See Appendix E) through a focused group discussion (FGD). A participatory model of FGD was facilitated to come up with six distinct elements of processed agreements, which was repeated for next three sessions.

\section{Qualitative Analysis (Descriptive Statistics and Content Analysis)}

The dialogue sessions were recorded in an audio-visual format with the consent of the participants. The dialectical relationship of participants was analyzed through listening and observing the records. I prepared a short journal capturing the major conversations after each dialogue session. The journal reflects how participants reacted when certain issues were brought to the surface. The category for analysis were narrowed 
by re-listening recorded communication and paralleling it with journal. This process is called propositional unit of coding data. These data were again summarized, explicated and structured by using inductive category development approach. Several reflections were done with my co-facilitator, in which we discussed how the energy and emotions of the group affected me and what needed to be done for me to remain neutral in the dialogue.

Pre- and post-dialogue questionnaires (see Appendices $2 \& 3$ ) were prepared with an intention to use descriptive statistics. It is interesting and important to synthesize the theoretical analysis with the actual numerical change in participant's perception on different components of identity. Such changes were measured and compared by creating a frequency table and participants' views are presented as bar charts. In addition, dialogue evaluation was conducted at the end of the final session. 


\section{Chapter 4: Research Findings}

The data collected from pre- and post-dialogue questionnaires are combined with participants' views collected during the dialogue. Moments from the different phases of dialogue are presented from the facilitator's observations, recorded during and after the dialogue. An initial assessment shows how participants initially self-identified. This includes gender, race/ethnicity, and religion, as well as participants' knowledge of and expectation from the dialogue.

Characteristics of the participants. The total number of participants for the dialogue was 11 and all of them were Portland State University students. The participants were from diverse national, geographical, and educational backgrounds, which enriched the dialogue process. Details are shown in Table 2.

Table 2

Characteristics of the Participants

Gender

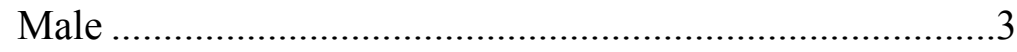

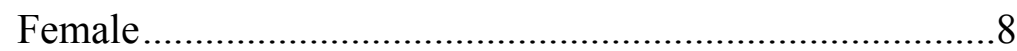

Age

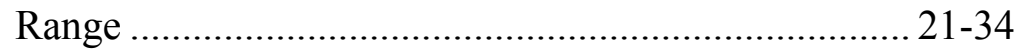

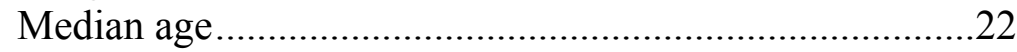

Religion

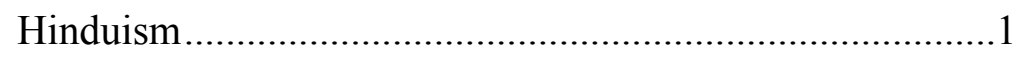

Christianity.............................................................

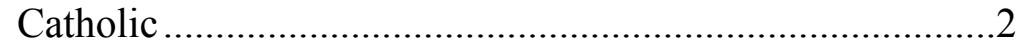

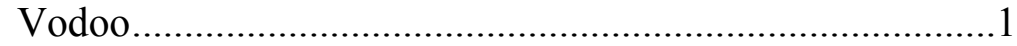

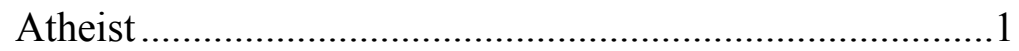

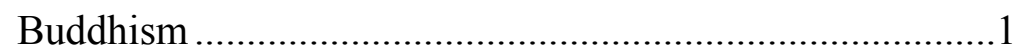

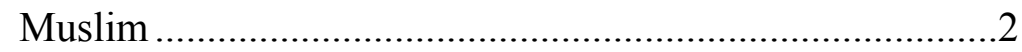

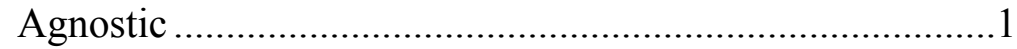

Not-affiliated ................................................................. 
Race/ethnicity

African-European..............................................................

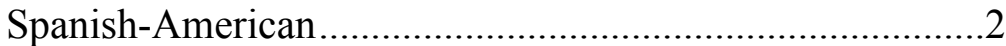

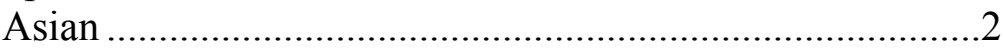

Asian-American ................................................................

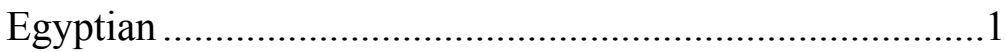

Egyptian-American ...........................................................

Latino-American ...............................................................

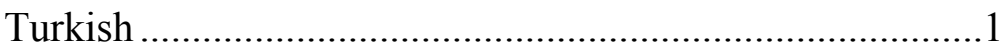

White American .................................................................

Educational Background

Engineering

Education

Social science

Level

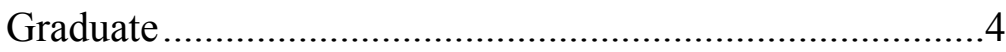

Undergraduate ..................................................................

Knowledge and expectation from the dialogue process. Of the 11 participants, two were familiar with intergroup dialogue, while the rest were new to the concept. Participants expected to:

- Practice empathy and understanding skills with members of different cultures through dialogue

- Improve skills to process others' stories and validate the stories with their own beliefs

- Be more culturally competent and learn intercultural communication

- Learn international career enhancement skills

- Increase inspiration on how dialogue can help people to better understand each other, deal with interpersonal conflict, and create peace 
- Understand how different identities - political, cultural, and social help to shape one's identity

In addition, almost half of the participants reported that they had previously discussed, explored, or attended trainings on identity related issues. The qualitative data presented in Table 2 shows the diverse ethnic and cultural backgrounds of the participants. The participants wanted to participate in dialogue to improve their understanding of themselves and others. The characteristics of the sample supported the process of selecting activities and developing dialogue inquiries.

Participants' association to social identity group. Participants were asked to identify the frequency with which they identified with social identity groups. The categories were national origin, gender, religion, race/ethnicity, age, socio-economic class, and sexual orientation. The scale used was $1=$ Never, $2=$ Rarely, $3=$ Once in a While, $4=$ Sometimes, $5=$ Often, $6=$ Almost Always, and $7=$ Always. Figure 1 shows participants' association to different social identity groups. The figure is based on participant's response to question on "How often do you identify yourself as a member of the following social identity groups?" (See Appendix B). Participants mostly associated with at least one social identity group. Most of the participants identified with gender and national identity. Some participants reported that they sometimes identified with race/ethnicity, age, and socio-economic class, and a few participants identified with sexual orientation as a major social identity group. 


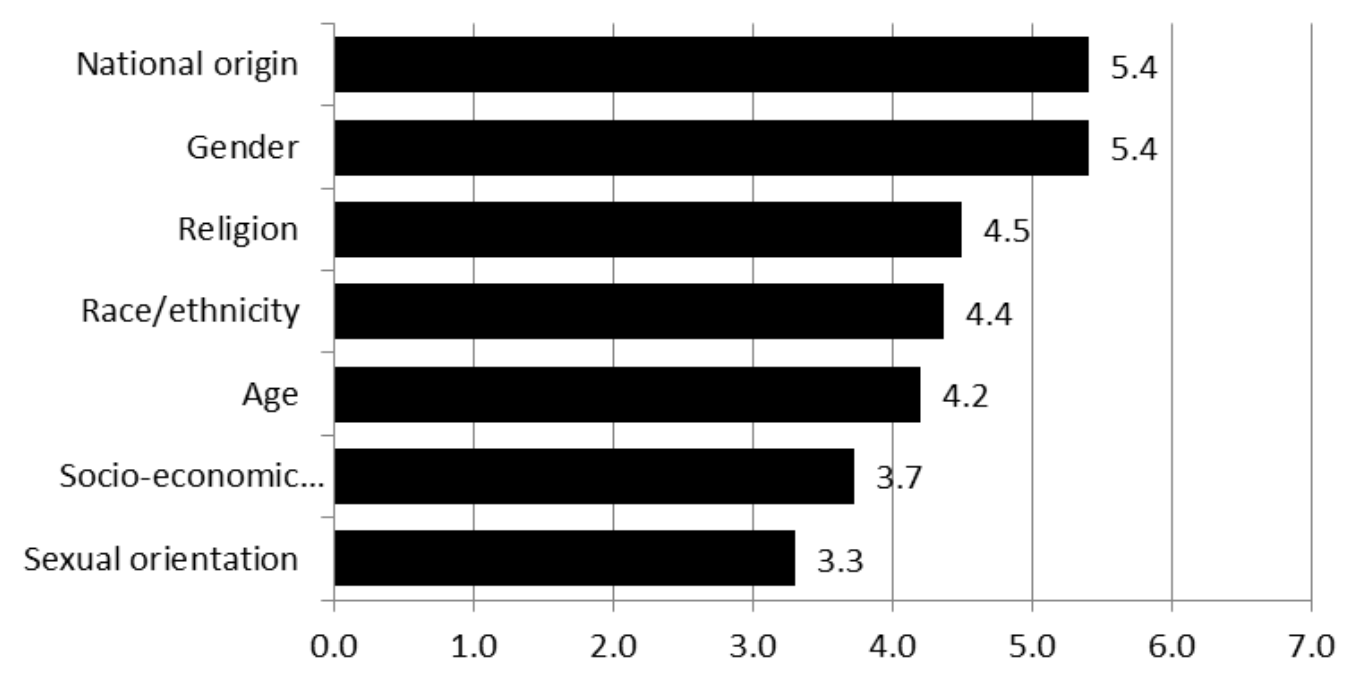

Never:1, Rarely:2, Once in a while:3, Sometimes: 4, Often:5, Almost always:6, Always:7

Figure 1. Participants' affiliations to social identity groups

\section{Identity and Identity-Based Conflict}

Participants' view on identity. Participants expressed slightly different views on identity in writing and sharing in dialogue. While writing their views on identity, some participants explained that identity is what an individual thinks about his or her social affiliations and interpersonal relationships with people in the society. How a person projects his or her identity to others is due in part to influences from culture and historical background, which help to shape behavior.

During the dialogue, one of the participants anxiously said, "Identity means pain." One of the other participants said, "Identity is struggle between perceived self and real self." One other view reflected identity as "Cause for doubts with others."

Identity-based conflict. Participants were asked to indicate how often they experienced identity-based conflict, on the same 1- to 7-point scale used in the previous 
question and in the context of the same seven identity categories (religion, national origin, socio-economic class, race/ethnicity, gender, age, and sexual orientation). These data show different types of identity-based conflict, which participants reported is more frequent in their day-to-day life. (See Figure 2). The figure is based on participant's response to question on "What kind of identity based conflict is more frequent in your life?" (See Appendix B)

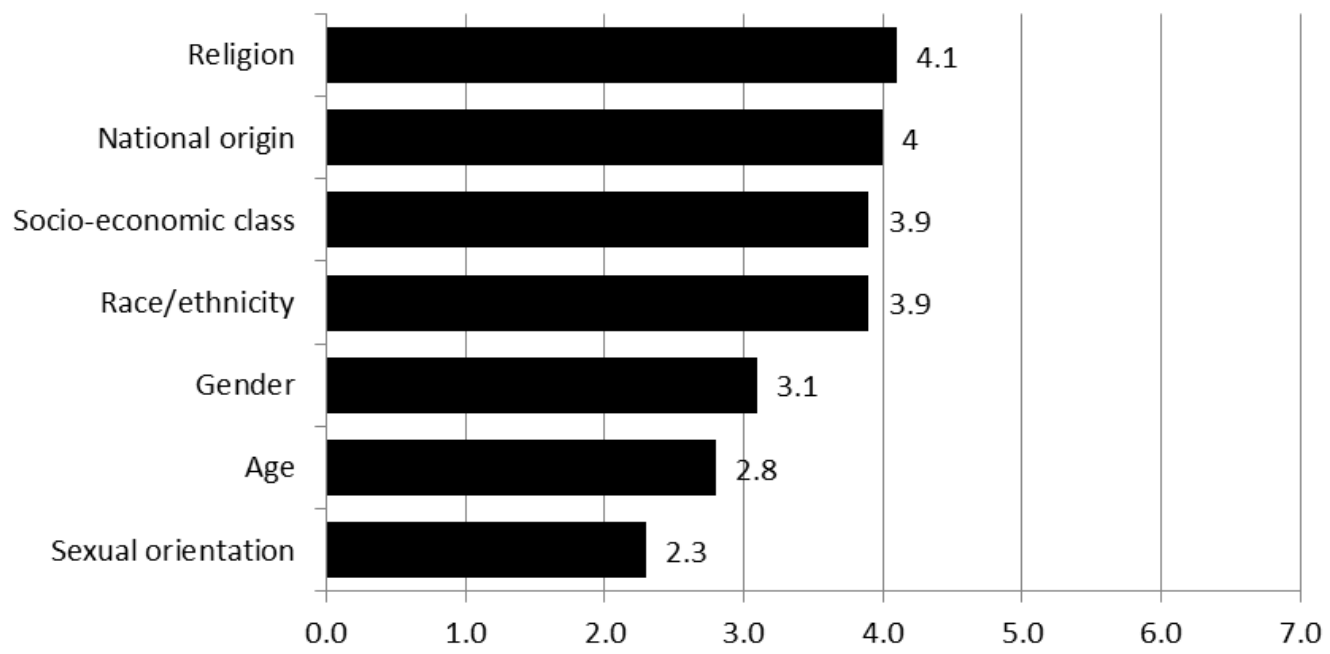

Never:1, Rarely:2, Once in a while:3, Sometimes: 4, Often:5, Almost always:6, Always:7

Figure 2. Participants' responses to identity-based conflict

Most of the participants explained that others confuse their identities with race and place of origin and do not try to understand that each person's identity is influenced by his or her experience rather than by skin color or language. Most of the participants related identity-based conflict from the perspective of gender, national origin, socioeconomic situation, and religion. 
Race/ethnicity. In support of the data shown in Figure 3, during an activity (see Appendix D and G) in the first dialogue stage, a Chinese-American female participant said, "This is what I always get from other while I interact, and I have been constantly struggling with my identity." She expressed this view when her activity partner made an assumption on how she looked, saying she was "nerdy" and "played Pokémon video games like other Asians. An Egyptian American female participant added,

"Being born as half Egyptian and half American is such a challenge for me. I do not know which side of culture I belong or what to follow. When I visited Egpyt, people said I am not an Egyptian as I look too white."

National origin. Asian Male participant said that nationality is part of people's identity and when nationality is reflected in behavior, sometimes conflict occurs. The conversations begin with Spanish-American participation view on her behavior in dealing with other. She said,

I am famous for being straightforward in my friends and family circle. If you are wrong and if you are hurting me, I am going to hurt you. At some point of life and in some situations, it is necessary and helpful to be straightforward.

Another Spanish-American female participant supported this view and said, "It's a Spanish thing. We do not sugarcoat when we do not support the idea that we do not agree. If this creates conflict, so let it be."

Upon hearing the view of two participants from two Spanish-American female participants, an African-American female participant said,

It is impossible to do that in Portland with Americans. I felt so conscious and strange with the idea of - you hurt my feeling. This term bothers me a lot. I am a straightforward person and say what they have to say but here I did that and realized I do not have friends anymore. It is impossible here, people false praise you.

A Nepali male participant explained, 
After hearing stories, I think nationality has a huge effect on shaping one's identity. I am from Nepal and we suppress our feeling to make other people happy. I also practice it when I encounter any such situation with my closed ones or even outside people and it does not mean I am sugarcoating, it is creating harmony and peace.

Gender. One of the Egyptian-American female participants expressed how conflict occurred between her mother and her because of confusion between her personal and social identity (gender and cultural identity). She said,

I think my participation in the dialogue and my ability to share my thoughts has been influenced by my gender and cultural identity. Women in my culture are not supposed to do certain things. I had a conflict with my mother because I expressed and opposed a political viewpoint during a family (including extended family member) dinner, which was organized, in my honor. She told me that I should not be that bold enough to answer back. She accused that I have changed because living in the United States changed me. I could not feel I belong to my own home. I am trying to find a place where I can call it a home.

\section{Participants' dilemma between personal and social identity. A Latino-}

American male participant shared on his confusion between his "self" and "perceived identity". He said he was staying at his parent's home because he cannot live by himself due to a bone-marrow health problem. Later, he shared his dilemma:

I am always an angry person. I was in complete denial stage of my life, always hid my emotions and pain, and let other things control my life. I am stuck and compelled to live with my parents because of my bone marrow problem. I wish to live in the dorm and be a normal person. I missed so much of my life. In my frustration, I always presented my angry-self to other without noticing why I was angry.

In addition, a Spanish-American female participant explained,

My Mom is an American and my dad is from Spain. Both of them divorced and she took off giving all responsibilities of my siblings at the age of 13. She took drugs and used to visit us now and then. My life was terrible. I now live with my maternal grandparents and I take care of them. However, they want me to move out their house as I graduate. I came here in search of a family and to take care of my old grandparents but I could not find one. This is why I do not believe in relationships 
and in order to sustain in the harsh world, I have to be direct and say what I have to say.

Participants' response to fear, prejudice, and discrimination. Participants were asked to indicate how often they responded to fear, prejudice, and discrimination, on the same 1- to 7-point scale used in the previous question and in the context of the same seven identity categories (religion, national origin, socio-economic class, race/ethnicity, gender, age, and sexual orientation). Most of the participants felt that they have been misunderstood and discriminated against because of their nationality, race, class, or gender.

Participants feel least judged on the identity based on sexual orientation and age. Participants shared that color of skin, accent and language, gender are seen more often while interacting with people different from their own identity group. Figure 3 shows their views on different types of identity where they feel most or least stereotyped. The figure is based on participant's response to question on "Have you ever fely being misunderstood and discriminated because of your identity?" (See Appendix B). 


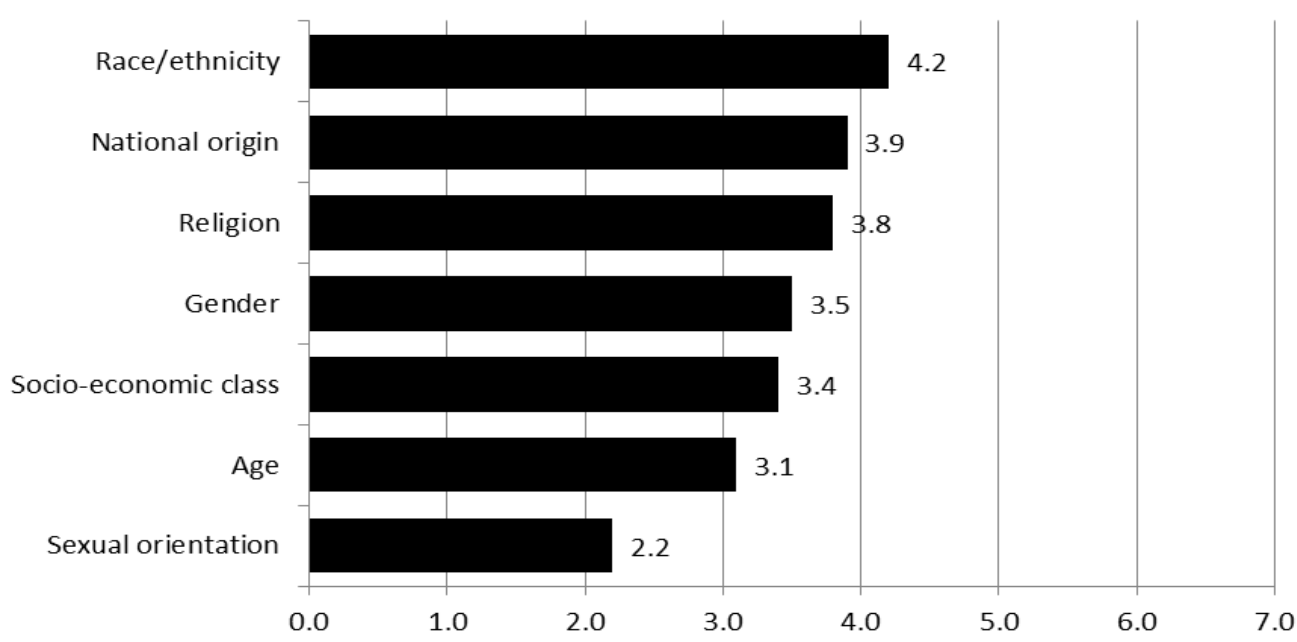

Never:1, Rarely:2, Once in a while:3, Sometimes: 4, Often:5, Almost always:6, Always:7

Figure 3. Participants' responses to fear, prejudice, and discrimination

Participants' fears with identity. In the first stage of dialogue (Instability in the group), participants generated the following statements, which are based on the activity on fear (see Appendix G).

- People will not listen to me because of my identity.

- I fear failing myself because of identity.

- I fear not being true to myself.

- I fear fulfilling others' expectations.

- I fear of isolation and rejection.

- I fear being judged.

- I am searching for my true identity

- I fear losing confidence in front of other people. 
- I fear being honest about my feelings, that I might hurt others' feeling, or that I will feel uncomfortable or lose my integrity by not being honest.

- I fear not able to develop my personality because of internal and external forces of society.

Participants' responses to discrimination, stereotype, and prejudice. An African-European female participant described how she felt discriminated against because of her accent:

I feel sad and frustrated when my professor and American friends make a face showing that they are tired listening me and making sense out of my English. I feel I am not heard enough and I cannot explain well to other. I just hate that look on their face.

A Turkish male participant said, "Because of my accent, I do not feel comfortable in interacting in the class."

\section{Perceptions of Identity and Identity Conflict}

Participants said that they no longer felt they would always be seen through the lenses of value judgment and assumption. A Latino-American male participant said,

I am no longer angry. I am not the same short, angry... that stereotyped guy anymore. I am happier than before because I found reconciliation within myself. Different identities like color of skin, language, gender no longer define me or I do not take those as criteria to understand others anymore.

Similarly, an Egyptian-American female participant said, "I am more aware of others' identity and also have reconfirmation on what I believe as my identity. I am a changed person on how I see myself and how I relate to other."

Another Egyptian female participant added,

I feel I understand more of myself and others. Dialogue made me aware of stuff that I had no idea about. It reconfirmed something in me that I really had. The fact that I was born and raised in a country with conflict and the way I was raised my parents that made me think culture, nationality, religion, social status, gender interfere your 
identity and how you become but at the same time I realized should not forget we all are become human being. Whatever things hurt you, can hurt me and we can perceive a same situation in a different way. You are hurt as much I am. I can identify with other's pain because I felt unique human connection as I did not feel judged and did not have to worry about where I come from.

Participants were asked to rate their feeling about five elements that they might feel when interacting with people whose identities are different from their own, using a scale of 1 to 10 , where 1 was low and 10 was high. The five elements were trust, engagement, openness, anxiousness, and excitement. The data were tabulated from the pre- and post-dialogue surveys. It was found that their levels of trust increased from 6.81 to 7.54. Their reported level of engagement also improved, increasing from 7.00 to 7.72 . Being open to others in sharing their thought processes increased from 7.00 to 7.63 , and level of excitement increased from 7.72 to 7.90 . However, the anxiety level increased from 4.63 to 5.54 . Figure 4 shows the averages of each element. The figure is based on participant's response to question on "How do you generally feel when interacting with people from social identity group different from your own?" (See Appendix C). The factors like trust, engangement, openness, anxiousness and excited are adapted from a guidebook on Multi-University Intergroup DIaogue Research Project ("University of Michigan," n.d.). 


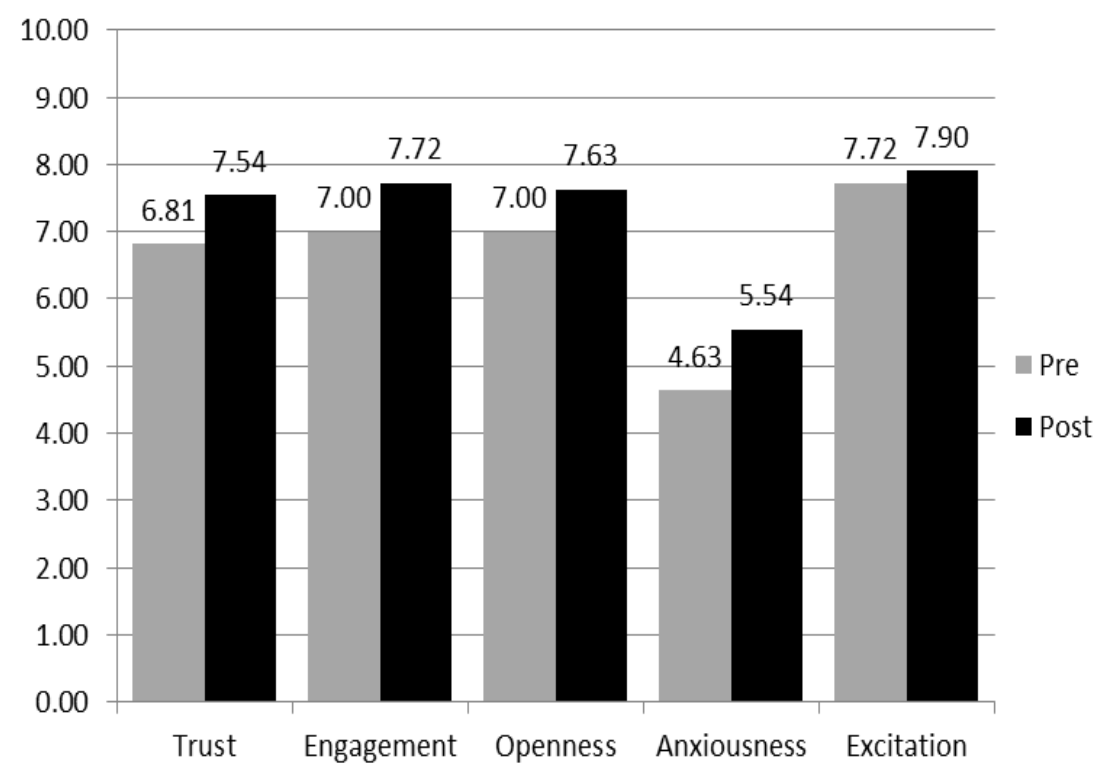

Figure 4. Participants' changes in perception

(Adapted from Multi-University Intergroup DIaogue Research Project-

Guidebook ("University of Michigan," n.d.).

Participants' scores reflected changes in five elements after interacting with people from different social identity groups.

Egpytian female participants said that she had doubts of being judged and was uncomfortable to share because of other Egpytian in the same room. She shared,

I was in a huge doubt how another Egyptian in the room will take my views. I was cautious and nervous all the time and felt uncomfortable sharing my views. Now, I feel more open to share my feeling even if there are people from my country. Here, I do not feel judged or watched. Having being accepted, listened to and see other feel safe and open about their stories made be feel enganged and empowered to share my own things.

Participants said they experienced a change because:

- Their belief was reinforced that dialogue is tool that can facilitate understanding between people of different identity groups 
- They saw that dialogue is a good way to channel internal conflict

- Dialogue increased their confidence to speak in groups

- Dialogue served as a reminder to avoid being judgmental

- Dialogue helped to see that they were not the only one who struggled with their identity

- They were empowered as they were able to discuss their fears

- They identified with people's pain and saw how they worked through it

- They saw that conflict is solved through conversation

- They were allowed time to be open-minded and to rationalize their view and other's behavior 


\section{Chapter 5: Analysis, Recommendations, and Conclusions}

In this chapter, I explain the linkages between identity and conflict, which account for the confusion between personal identity (the "self") and social identity. In the study, dialogue was the method used to address identity-based conflict. First, it was learned that struggle and confusion between personal and social identities creates both intra- and interpersonal conflict. Second, not all identity-based conflict causes confusion in "self." Third, deeper conversation, reflection, and group empathy on issues of identity help people to understand "self" and "other."

\section{Analysis}

Identity and conflict. Identity consists of different types and each carries a different aspect to it. For example, an individual's gender identity is different from his or her national identity, and these identities play various roles. Because of its various roles, identity cannot exist alone without conflict. An individual carries different identities in a similar or a different situation. Different identities are derived from distinct value and belief systems. When these values and belief systems collide with personal interest, conflict occurs. The identity-based conflict evolved in dialogue was primarily focused on identities such as gender, national origin, and race/ethnicity.

In the first stage of dialogue, the meaning of identity was presented as a social construct. However, defining identity and understanding its nature displayed differently in the last stage of dialogue. Later, identity was defined as self-constructed, which implies that when identity is affected by the socially constructed identity, it can change or remain the same. If an individual lives his or her life according to the expectations of others, then he or she develops fear (see Appendix G). 
For example, an African- European female participant read the statement "fear of fulfilling other's expectation", which defined how struggles between inner self and social identity create fear and isolation within. She explained,

I am an individualist from a collectivistic society. The way I think does not match with the expectation of my family members. I feel expectation of performing certain roles as a female confines my inner self. I feel very divided and lost arguing with my family members.

Her statement confirms how an individual can be troubled in figuring her real identity and struggles to follow social norms and values. This confirms that personal identity "self" and social identity are two different concepts and the idea of putting them together raises serious questions of coherence (Sen, 2009).

Identity-based conflict. An individual who struggles between proprium to self and looking glass self faces a different identity-based conflict. It was found that gender, national origin, and race/ethnicity have been sources of conflict, confusion, and discrimination for the participants.

Gender-based identity conflict. The majority of the women participants felt strongly about conflict and confusion in their gender roles. Personal identity and values intervene in gender roles and responsibilities. The dialogue revealed that it is difficult for women to express their "self" as they are limited by their gender roles and norms. As explained in Chapter 3, many participants feel conflict within and with others because of inability to determine what their real values are. The case of African-European female participant explained in facilitator's observation section in chapter 3 shows how gender identity makes females vulnerable, limited and confused. For many women, it is difficult to ignore gender values because gender roles (responsibility being male and female) are 
predefined very early of their life. This shows that values are deeper than personal interest and strongly connected with identity (Forester 1999). Her struggle comes from her confusion in her values as a person coming from traditional collectivist society conflicting with her interest to become an independent woman.

Similarly, a Spanish-American female participant related how her current personal identity is an outcome of her relation with her divorced parents and how she views everything through the eyes of feminism (Refer chapter IV pg.35-36). Most of the conflicts are present in the lives of these participants because they did not try to separate their other identities from their personal identity, i.e., their "selves" (Sen, 2009).

Overlapping the "self" with other identities prevents them from understanding their core needs, as well as understanding others.

Nationality/race and ethnicity-based identity conflict. Participants, coming from multiracial backgrounds or different nations and speak English as a second language focused on nationality/race and ethnicity as a basis for identity conflict. The formation of ingroups and outgroups during the dialogue confirmed issues like nationality and race polarize an individual's thoughts. Participants faced conflict with the "self" when they felt misunderstood and mistreated by others based on their appearance or accent, rather than because of confusion between their individual value/interest and social values or norms. Participants faced internal conflict only when the "other" evoked or doubt his or her identity, and only then did questions surface about "self." Thus, self-doubt did not occur until someone made a critical remark. Conflict in these categories of identity is based on how an individual is being perceived by others, not how the "I" perceives itself or what the "self" wants to project to others. The power of emotional attachment to 
nationality, ethnicity, and race makes an individual narrow his or her self-interest (McCauley, 2001). This is because national/ethnic identities are strongly rooted and influenced by shared bonds with distinct values and origins with a particular group (Horowitz, 1985). Therefore, such conflicts exhibit ingroup and outgroup phenomena, where an individual from the ingroup feels more confident in associating with his or her group only (Allport, 1954).

Dialogue in identity-based conflict. All four distinct stages of dialogue (Senge, 1994) occurred in the dialogue, and the facilitated conversation helped participants share, understand, and resonate with each other stories. Participants felt and expressed different sets of emotions through the dialogue process.

In the first stage of dialogue (Instability of the group), participants felt uncomfortable, targeted, and forced to share their views at various stances. Such uneasiness was later reflected by the participants to come from the preconceived thought process of their "self" and fear within their "self." These preconceived thoughts and fears were explored through activities and sharing of personal stories in the dialogue. The uneasiness was further challenged when participants struggled to connect with the ingroup. Some felt closer to participants with gender conflict, while some connected with stories of national and racial identity. This phenomenon is natural in dialogue and important to an individual to maintain his or her self-esteem (Fisher, 2000; Gurin, Peng, Lopez, \& Nagda, 1999; Stephan \& Stephan, 2001; Taylor \& Moghaddam, 1994; Wayne, 2008).

When participants searched for commonality in others, listening and showing empathy occurred. These behaviors were possible through a well-facilitated dialogue, 
which is required for "contact hypothesis" (Allport, 1954; Pettigrew, 1998). In the second stage of dialogue (Instability in the group), participants came together in mutual acceptance while some participants suspended their thoughts. Participants self-reflected on why some participants can accept the same thing and why some cannot. This selfreflection led to "crisis of suspension" where different opinions were shared, accepted, and defended. Participants do not necessarily need to agree, but such positive intergroup contact helped participants to dialogue further to reach for a mutual goal. Frølund Thomsen (2012) indicated that intergroup contact makes individual or a group more tolerant, because enduring contact situations promote familiarity through individuating information.

During this stage, participants realized some parts of their identity, such as national origin, could not be changed. Further, these unchangeable identity elements have stronger values to the "self". This identity was found to be different from personal identity and did not have role in intrapersonal conflict of the participants in the dialogue. Participants expressed strong feelings as they started to think how national identity was an important part of their own identities when they are outside of their countries and cultures.

Allport (1954) and Pettigrew and Tropp (2005) reported that intergroup contact is a source of mutual acceptance and helps reduce prejudice toward others. Such contact in the dialogue helped participants to empathize with each other and realize each individual's struggles. This phenomenon matches two specific parts of Allport's hypothesis: (a) specific attitude change (liking the person with whom contact occurred 
more than expected) and (b) attitude amelioration (adopting a less negative attitude toward the group; (Desforges, Lanicek, Lord, Ratcliff, \& Scarberry, 1997).

In the third stage (Inquiry in the group), deeper inquiries prompted participants to become aware of their situations and motivated them to constantly check the feelings of others. Such inquiries helped participants to understand others, and reconfirmed different aspects of their own identities. Dialogue was helpful in creating new meaning of their personal identities. Participants said that dialogue was helpful and created a safe place for understanding oneself and others.

In the last stage (Creativity in the group), participants expressed that they no longer thought a particular identity described who they were. Dialogue reduced anger and frustrations. Pain and emotion are universal and do not change with people's identities. The dialogue also reassured participants that one's social identity is fluid, and it is the individual "self" who determines with which social identity he or she wants to be associated. Therefore, an individual has a choice of determining his or her social identity. In addition, dialogue is an open conversation and can also produce collaborative output that can manifest its true transformative power.

\section{Analysis of the Dialogue Process}

The dialogue process proceeded through the four phases of dialogue (Senge et al., 1994). The process led to discoveries involving various aspects of the participants' identities and their intra- and interpersonal conflicts.

Phase I: Instability of the group. The dialogue process encountered its first crisis when participants shared views on their definitions of identity and their affiliations to different social identity groups. Participants gave generic explanations of identity in 
the questionnaire while responding critically to the meaning of identity during the dialogue discourse. The reason for getting a different set of explanations during the dialogue is likely due to the activity being conducted before the dialogue on the first session (Observation versus Assumption-Value judgment; see Appendix G). The outcome of coming together and talking about issues had a strong impact, compared to explaining the same issue in writing. It appeared that when things are explained using words (verbal) and gestures, emotions play an important role in shaping the feelings evoked by the words.

During the activity, participants were divided into groups of two and asked to observe each other for 3 minutes and write their assumptions about their partner, based on their observations. Participants were given time to explain what they thought about their partners. Most of the participants were amused at how observations based on assumptions can be confusing and misleading.

The Chinese-American woman's sharing of her struggle while growing up resembled experiences of some of the participants present in the dialogue. The painful experiences and challenges she shared slowly built an energetic cohesion within the group. However, some participants did not react to it at all and felt a bit amused by seeing other's reaction and sharing of their personal stories. The discomfort was observed through their posture and facial gestures. Some were seated crossing their arms and some placed their hands on their chin with a facial remark on their forehead; yet they treated the situation as normal and apparently saw no need to react. Those who reacted by sharing their stories were thoughtful and tried to empathize with individuals who they realized felt the same pain they themselves experienced. 
The icebreaker activity, Observation versus Assumption-Value Judgment (see Appendix G), opened up the conversation and participants entered the first stage of dialogue - the stage of inquiry and instability of the container. Going deeper, they explored the meaning of identity, which inspired participants to discuss further why and how identity creates suffering within a person and creates misunderstanding and conflict with others. During the activity of "fear in the hat" (see Appendix G), group shared and talked about their fear with identity, which took the dialogue to another level. Participants shared that fear caused confusion with their inner "self," as well as with their family members, friends, and colleagues.

Phase II: Instability in the group. The activity conducted during the second session was focused on understanding the one-thing participants feared about their identity. The purpose of the activity was to reveal different aspects of identity-based conflict. Participants were asked to write what they feared on a piece of paper. The papers were collected and placed on the floor, and each person was asked to pick one and read it out loud in front of the group. They were given the option of relating and sharing their experience regarding the particular statement.

Acting as the Facilitator, I read the statement, "Being honest about my feeling I might [have] fear of hurting other's feeling or I will feel uncomfortable or [not] true to myself by not being honest." I noticed the White American male nodded with a humming tone, saying "Huh." When asked the reason for his reaction, he said that this statement raised awareness and curiosity on how this can affect a person and his or her relations to others. 
Interaction on issues of national origin prompted participants to think about how their national identity shaped their personal identity and guided them on how to deal with people from different national identity groups. Such self-reflection led to "crisis of suspension" (Senge et al., 1994) and different opinions were shared and defended as needed. It was also observed during this stage of dialogue that participants represented themselves based on their national identity. Participants who felt the need to be straightforward and direct formed a group and claimed the other group's behavior was sugarcoating. The accused participants defended themselves, saying that their identity and how they deal with others is not sugarcoating, but it is part of their national identity.

It was then a White-American male participant intervened and said,

I was born and raised in Eugene in a white American culture. I never felt the need to be direct and did not feel conscious on what other people say to me, I always try to make sure that I am not hurting other people with my words. I do not see my behavior is result of being a white or brought up in a white American culture. I think it is more internal thing. It's like you are talking to your inner-self and being true to yourself.

It appeared that his earlier humming mode, his interest in being true to his inner self and being honest, and his above explanation all helped him to inquire of his inner self for a clear meaning of how his personal identity is different from his social or racial identity. The participants listened and observed his sharing positively, and most of them said they also supported his viewpoint.

The confusion and crisis still prevailed in the dialogue, but it slowly moved to another level. Some participants felt the need for deeper inquiry, and some pulled back from the discussion. Participants who were speaking a comparatively longer time looked thoughtful, allowing themselves to listen more to the participants who had just started to share their viewpoints. The conversation on influence of national and racial identity on 
individual identity showed how social contact between different groups can lead to a collective thought process.

It was also observed that some female participants were speaking a comparatively longer time than male participants, while some other female participants had hardly shared their thoughts. I opened a dialogue, asking if such phenomena were occurring because of their various identities.

Out of eight female participants, seven shared that oppressive gender norms and rules defined their ability to behave and present themselves in certain ways outside of their house. However, an African-American female participant and two SpanishAmerican female participants said that they were overcoming such gender identity roles by expressing their views and even opposing existing roles of women as subservient. And, this was well reflected in their dialogue participation styles as they actively participated and expressed their opinions to the group. One Chinese-American participant expressed that she liked to talk whenever it was needed, and it had nothing to do with her gender identity. However, three male participants thought that gender identity was not likely to shape their behavior and had no connection with their participation styles. Instead, they mentioned language barriers, a tendency to listen more, and talking whenever needed, all of which defined their participation style in the dialogue.

Phase III: Inquiry in the group. The conversation on how identity affects one's behavior, as well as how people deal with the inner self and outer world, helped participants to identify the one thing that bothered their souls and created conflict with 
their loved ones and with the outer world in general. This led the group toward deeper inquiry in conflict related to gender, national origin, and racial identity.

A Spanish-American female participant's painful sharing intensified the emotions, and people started displaying a sense of separateness from each other. One of the Chinese-American female participants left the room, and some of the remaining participants showed tears in their eyes. Such moments created a deep silence in the room and triggered emotions from many, including the ones who had been participating less in the dialogue. Other participants inquired and tried to understand why and how our relationships to others affect our personal identity and how that in turn creates conflict within "self" and with others. Different participants shared their experiences on how an individual's role to fulfill multiple social identities in a relationship—-for example, gender, cultural, national and racial identity—damages the "self," which then creates conflict with the other person. This helped the group explore "victim self" and "perpetrator self" in the context of identity-based conflict. It was revealed that an individual could express both selves in a conflict situation; thus, the person needs to decide which "self" he or she wants to present to the world.

The Latin-American male who said earlier that he was proud to be living with his parents suddenly exploded with anger when the group talked about victim and perpetrator self. His struggle about what he thinks about himself and what others expect of him resonated with an African- European female participant and made her realize that her beliefs about how individualist she was were completely false. I observed that she was representing herself as an individualist because she has no other choice or alternative. Deep inside she wanted her husband to take all the financial responsibilities and take care 
of her and her son. Thus far, her expectation of her husband had not been fulfilled, so she felt stuck in a relationship and, like an individualistic persons she wanted to move out of the marriage. Her inner self still desired belonging, clinging to a collective traditional belief system where gender roles related to financial responsibility between male and female are predefined. During the fourth week of dialogue, participants realized that the cause of problems and conflicts does not exist just because one belongs to a certain race or speaks a certain language or belongs to certain religion or gender.

Phase IV: Creativity in the group. This last stage of dialogue showed evidence of changes in the definitions of identity for the participants. Some no longer identified with the definition they shared in the first session. They did not feel their social identity could define their inner selves or personalities. A Turkish male participant shared that,

After hearing all the story, I feel my identity has been changing constantly. You cannot always define yourself with identity that your mother and father gave to you or your nation gives to you. You are more to it.

In this stage, it appeared dialogue-reconfirmed participants' confusion about their identities. People realized that not listening or reflecting enough in a conflict or any daily life situation changes their behavior without their awareness. Participants found new meaning to their identity and overcame pain, anger, frustrations, confusion and judgements about their idenitity. They felt accepted, listened to and respected during the dialogue. One of the Korean female participants shared that it was difficult to confront her parents in Korea when they told about her changed bahaviour. She was constantly told, "you have now become an American". She said that her confidence and knowledge to talk about her new identity with her parents has positively changed because she is able 
to identify her "self". She said that she is now more comfortable to talk with her parents without avoiding or confronting them.

\section{Theoretical framework}

Figure 5 shows the framework of the study. It is derived from the findings and the study on self, identity, identity-based conflict, and dialogue. The figure shows that the individual self has two aspects: (a) Proprium to self(Allport, 1954), where an individual thinks of his or her individual values and interests; and (b) the looking glass self (Cooley, 1902), where an individual thinks he or she is what others perceive him or her to be). The study on dialogue with identity based conflict revealed if there is confusion and conflict between these two "selves," then an individual faces conflict. Such conflicts are based on his or her various identities (gender, national origin, religion, race/ethnicity). The conflict can be both intra- and interpersonal conflict. If such conflicts are addressed through a dialogue, then an individual gets an opportunity to reflect on "self", find deeper and new meaning to self. 


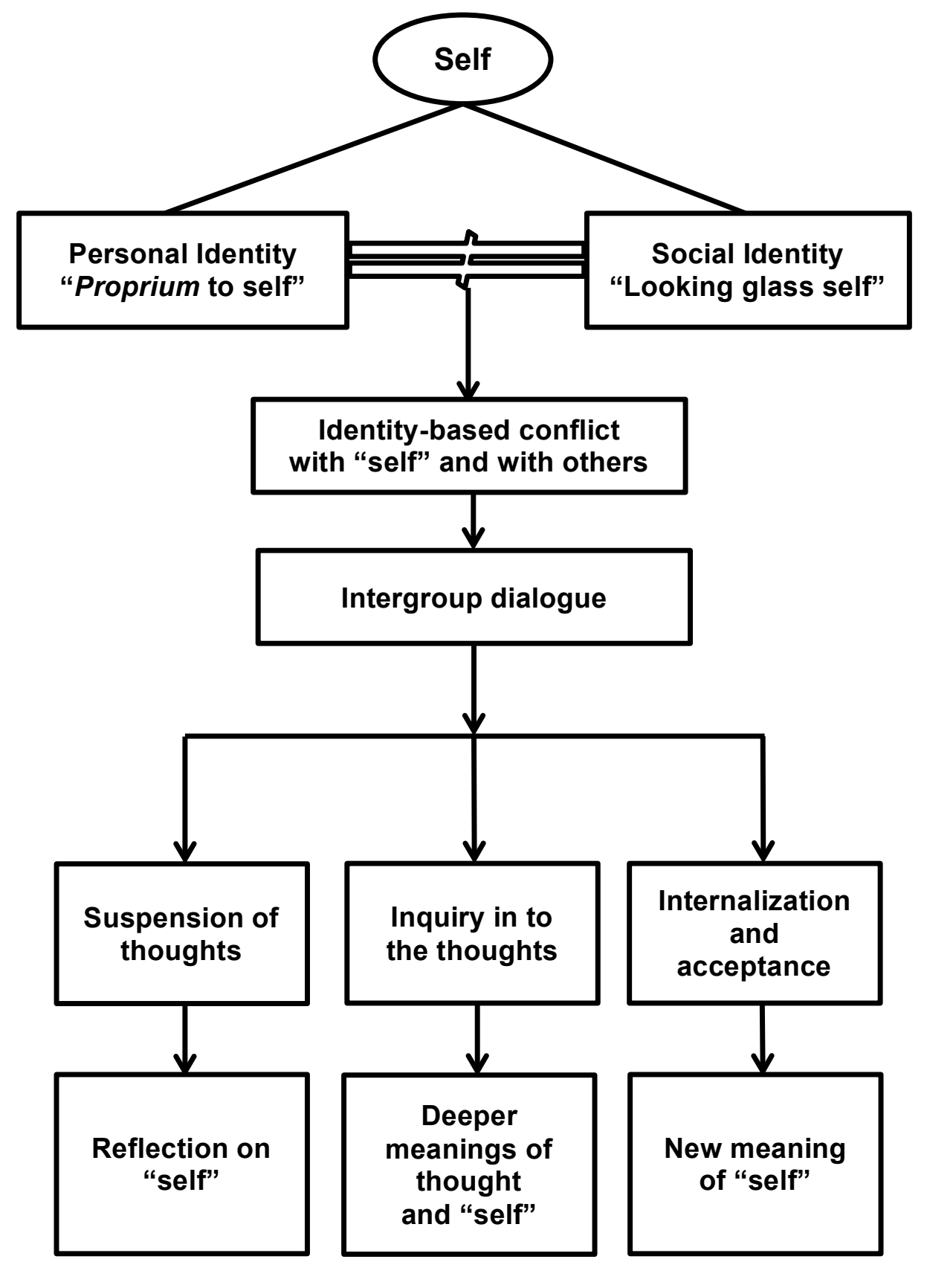

Figure 5. The theoretical framework

Adapted from Theories of Perception and the Concept of Structure by F. Allport, 1955, New York: Wiley; Human Nature and the Social Order, by C. H. Cooley, 1902, New York: Charles Scribner's Sons; David Bohm: On Dialogue, by D. Bohm, 1991, David Bohm Seminars, Ojai, CA. 


\section{Emerging Questions for Further Research}

The five weeks of dialogue raised some interesting aspects for future research. The participants in the dialogue were not in conflict with each other. It would be interesting to study how participants (University studens) with conflict have reacted or behaved in similar dialogue settings. Also, dialogue between faculty members, administrative offices and students might have brought a different result. This dialogue is based on a broad topic of identity and as the dialogue progressed focused and narrowed on topic, which the group focused and shared more. If the dialogue is based on a focused theme from the start day then deeper exploration on topic might be possible.

Dialogue consisted some of the participants from the same country and country affected with war. It would be interesting to conduct a dialogue to see if participants from war-affected country are brought together to dialogue. Would the process allow participants to feel safe or feel more vulnerable? The research has 8 female and 3 male participants. It can be further researched if number of male and female has any relation with participant's focus on gender based identity issues.

\section{Limitation of the Study}

The dialogue was conducted with university students during week 5 of the academic session (fall term), and this affected the dialogue session. The dialogue could not be conducted more than five weeks (two hour each week), including one week for the two-hour orientation. Two of the student participants attended inconsistently. They were not present in the second and third weeks of the dialogue, and their absence affected the flow of process. Also, due to technical difficulties, video recording did not last more than 
25 minutes per session from the second week. Therefore, the discourse analysis was based primarily on audio recordings.

I served as the lead facilitator. My participation in the activities might have encouraged participants to open up more in the dialogue session. I think this because participants do not only perceive me as facilitator but some one who also takes part in activities as they do. My participation in the activities was intended to create cohesion in the group and break up any hierarchy that appeared before convening to dialogue. The co-facilitator participated in the dialogue and shared a few opinions to encourage participants to share their insights. Care was taken to ensure that the co-facilitator's participation did not influence the views of participants.

\section{Recommendations}

The content of this research consisted of a dialogue. Several recommendations can be made in order to persuade administrators to make dialogue a permanent fixture at the university. The following are the recommendation for conducting the inter group dialogue.

1. Diversification of the themes

Identity is a great thematic area but there are several components and understandings on identity. Any future dialogue should involve different identity themes. Moreover, students' interests and the campus environment can be taken as some of the sources for defining themes.

2. Process and length of the dialogue

A dialogue should contain more sessions, possibly extending beyond the term length. There should be a clear plan to discuss the purpose of the research to 
gain the understanding of the participants. Considerations should be given to participants who want to use their learning in a creative way.

3. Institutional oversight

A university institution should provide oversight of the dialogue as necessary to institutionalize the process. Dialogue needs to adhere to strict procedural and confidential guidelines to maintain the privacy of the participants.

Additionally, action-based projects could result from the dialogue.

\section{Larger pool of participants}

From the research, it is clear that there is a need for dialogue among campus committees. Religion was one of the themes that could not be covered at the dialogue but requested by participants. Having a larger pool of participants could provide a critical mass of participants for each topic.

5. Education and Research

One experiment that was successful in the facilitation was to use the study of dialogue with the group as a mechanism to teach the utility of dialogue during the actual dialogue. This process has the dual effect of communicating practical knowledge of dialogue, as well as knowledge about the process and purposes of dialogue. Maintaining research components could also help to document the utility of the dialogue, its effect, and its impact on participants. In addition, the use of activities helped create trust and encouraged participation. 


\section{Reflection}

Intergroup Dialogue class that I took in Fall of 2012 inspired me to conduct this study. The class and the dialogic method, which was used, for instruction not only provided me a tool to work with other groups but also helped me to come out of my personal issues. One of the main lessons, I learned as a facilitator, in that class was to overcome my own anxiety, which I used during the course of this study in dialogue sessions. It was very challenging to remain neutral and hold emotions in intense situations. Therefore, "pausing for few seconds" helped to overcome such challenges. I realized that reflecting individual emotional energy to the group helped participants to connect with remaining participants. In such situations, asking group to check themselves and verbalizing their emotions and body language was helpful. Asking questions like "I noticed some of you sighed/ have tears/ left room, are there any specific things that you feel like sharing to the group?" This helped me to step back and allowed other participants either empathize or ask clarifying questions.

Activities in dialogue helped participants to come together and share. It also helped to break barrier because some of the activities were fun exercises and created joyful and laughable moments. I found having participants from same racial or national background in dialogue help overcome some of their identity related confusions.

I felt I relate to most of their stories and was tempted to share my own- my struggle with being a foreigner or my confusion with "self" and my other identities. However, I restrained myself throughout the process. This dialogue helped me to be a better listener, practice mindful listening skills. It also helped me to be less judgmental and comment only when I get a chance to interact well with people. 


\section{Conclusion}

The intergroup dialogue followed Senge's (1994) four stages of dialogue and through these stages various identity-related issues unfolded. It was learned that if a safe space is provided to dialogue, people feel free to share their personal stories.

Participants' views collected through the pre- and post-dialogue questionnaires reflected their feelings about the dialogue. Information was also collected about their association in certain identity groups, their existing identity-based conflicts, and their confusion over identifying with particular identity groups. Participants' stories, reflections, inquiries, and clarifying questions shared by the participants led to the development of the following statements:

- National, racial, and gender identities are the major identities that participants thought affected their inner selves and their relationships to others. However, not all identity-based conflict causes internal conflict and confusion within "self." It is revealed that identity-based conflict such as gender has significant role in creating confusion within "self" and is a cause for creating intra and interpersonal conflict. Identity such as "national origin" has lesser role in creating conflict within "self” but is definitely a reason for inter-personal conflict. In case of race/ethnicity, it causes conflict within and with others depending on situation and problems.

- Combining different identities with participants' personal identity "self" when dealing with a problem was the cause of intensified conflict and also restricted their understanding of others' viewpoints. 
- Different identities (racial, national, gender) do not define an individual's ability to understand people with different identities. It is an individual's inner self and personal identity that defines a person's behavior, thought process, and how he or she sees the outside world.

- Intergroup dialogue can be a tool to analyze identity-based conflicts.

- Intergroup dialogue helped to bring change in the perceptions of participants who experienced an issue with identity-based conflict. Evidence for this change was their increased level of trust, openness, and engagement in interacting with people outside their own identity groups. 


\section{References}

Adams, G. R.,\& Marshall, S. K. (1996).A developmental social psychology of identity: Understanding the person-in-context. Journal of Adolescence, 19, 429-442.

Allport GW. 1954. The Nature of Prejudice.Reading, MA: Addison-Wesley.

Allport, F. (1955). Theories of perception and the concept of structure. New York: Wiley. Babbie, Earl (2001). The practice of social research (9th ed.). Belmont: Wadsworth.

Bohm, D. (1990). David Bohm: On dialogue. David Bohm Seminars, Ojai CA.

Berelson, B. (1952). Content Analysis in Communication Research. Glencoe, Ill: Free Press.

Brunsch, C. (2007). Stereotyping as a Phenomenon in Intercultural Communication. GRIN.

Campbell, B. G. (1976).Humankind emerging. Boston: Little, Brown.

Cayer, M. (2005). The five dimensions of Bohm's dialogue. In: Banathy, B.H. and Jenlink K. (Eds.) Dialogue as a means of collective communication. New York: Academic/ Plenum Publisher.

Collier, M. J., \& Thomas, M. (1988). Cultural Identity: An Interpretive Perspective. In Y. Y. Kim \& W. B. Gudykunst (Eds.), Theories in Intercultural Communication (pp. 99-120). Newbury Park, CA: Sage.

Cooley, C. H. (1902). Human Nature and the Social Order. New York: Charles Scribner's Sons

Daux, K. (2001). Social Identity. Encyclopedia of Women and Gender. Vol 1 and 2. Academic Press 
DeBowes, M.M. (2006). Intergroup Dialogue:a promising Practice of Cross Cultural Engagement. (Online) available at:

http://www.uvm.edu/ vtconn/?Page=v27/debowes06.html Accessed, March 24, 2014.

Desse A.1, Rogge M. E, and Garlington S.B (2006). Using Intergroup dialogue for Social Justice and Change. Social Work 51(4).

Deforges, D. M., Lord, C. G., Ramsey, S. L., Mason, J. A., Van Leeuwen, M. D., West, S. C., \& Lepper, M. R. (1991). Effects of structured cooperative contact on changing negative attitudes toward stigmatized social groups. Journal of Personality and Social Psychology, 60, 531-544.

Epstein, S. (1973). The Self- Concept Revisited Or a Theory of a Theory. American Psychologist. P 404-416.

Fisher, R. J. (2000). Intergroup Conflict. In M. deutch, and P.T. Coleman (eds. The handbook of conflict resolution.. San Francisco: Jossey Bass.

Forester, J. (199). Dealing with deep value differences. In L. Susskind, S. McKearnan, \& J. Thomas-Larmer, (Eds.), The consensus-building handbook: A comprehensive guide to reaching agreement. (pp. 463-493) Thousand Oaks, CA: Sage.

Frølund Thomsen, J. P. (2012), How does Intergroup Contact Generate Ethnic Tolerance? The Contact Hypothesis in a Scandinavian Context. Scandinavian Political Studies, 35: 159-178.

Gurevitch, Z.D. (1989). The Power of Not Understanding: the meeting of Conflicting Identities. Journal of Applied Behavoral Science. 25(2). P 161-173 
Gurin, P., Dey, E. L., Hurtado, S., \& Gurin, G. (2002). Diversity and higher education: Theory and impact on educational outcomes.Harvard Educational Review, 72(3), $330-366$.

Gurin, P., Peng, T., Lopez, G.E., and Nagda, B.A. (1999). Contest, identity and intergroup relations. In D. Prentice and D. Milller (EDS.) Cultural divides: Understanding and overcoming group conflict. (pp 133-170) New York: Russel Sage Foundation.

Holsti, O.R. (1969). Content Analysis for the Social Sciences and Humanities. Reading, MA: Addison-Wesley.

Horowitz, D. L. (1985). Ethnic Groups in $\mathrm{Con}^{-}$ict. University of California Press.

Kohlbacher, F. (2006). The Use of Qualitative Content Analysis in Case Study Research. Forum Qualitative Sozialforschung / Forum: Qualitative Social Research, [S.1.], v. 7, n. 1, Jan. 2006. ISSN 1438-5627.

Kracauer, Siegfried (1952). The challenge of qualitative content analysis. Public Opinion Quarterly, 16(4), 631-642.

Krippendorff, K. (1980). Content Analysis: An Introduction to Its Methodology. Newbury Park, CA: Sage.

Kuh, G. D., Kinzie, J., Schuh, J. H., Whitt, E. J., \& Associates (2005). Student success in college: Creating conditions that matter. San Francisco: Jossey-Bass. Lopez, G.E., Zuniga, X. (2010). Intergroup dialogue and Democratic Practice in Higher Education. New Direction for Higher Education. 152 pp 35-42

Mayring, P. (2000). Qualitative content analysis [28 paragraphs]. Forum Qualitative Sozialforschung / Forum: Qualitative Social Research [On-line Journal], 1(2), 
Art. 20. Retrieved from

http://www.qualitative-research.net/fqs-texte/2-00/2-00mayring-e.htm

Mayring, P. (2002). Einführung in die qualitative Sozialforschung, Eine Anleitung zu qualitativem Denken (5th ed.). Weinheim: Beltz.

McCauley, C. (2001). The psychology of group identification and the power of ethnic nationalism. In D.Chirot\&M. E. P. Seligman (Eds.), Ethnopolitical warfare: Causes, consequences, and possible solutions (pp. 343-362).

Washington, DC: United States Institute of Peace.

Nagda, B., \& Gurin, P. (2007). Intergroup Dialogue: A critical-dialogic approach to learning about difference, inequality, and social justice. New Directions for Teaching and Learning, 111 (4), 35-45.

Pettigrew, T. F. 1998. 'Intergroup Contact Theory', Annual Review of Psychology $49,68-85$.

Pettigrew, T. F., \& Tropp, L. R. (2005). Allport's intergroup contact hypothesis: Its history and influence. In J. F. Dovidio, P. Glick, \& L. Rudman (Eds.), Reflecting on The Nature of Prejudice: Fifty years after Allport. Malden, MA: Blackwell.

Ritsert, Jürgen (1972). Inhaltsanalyse und Ideologiekritik. Ein Versuch über kritische Sozialforschung. Frankfurt a.M.: Athenäum Fischer Taschenbuch Verlag.

Saunders, H. (1999). A Public Peace Process: Sustained Dialogue to Transform Racial and Ethnic Conflicts. New York, St. Martin's Press.

Schoem, D., Hutardo, S., Sevig, T., Chesler, M., and Sumida, S.H. (2001). Intergroup dialogue: democracy at work in theory and practice. In D. Schoem and S. 
Hurtado(Eds.), Intergroup dialogue: Deliberative democracy in school community, and workplace. (PP 1-21). AnnArbor. University of Michigan Press.

Sen, A., 2009. The fog of identity. Politics, Philosophy \& Economics, 8 (3), 285-288.

Senge, P. (1990). The Fifth Discipline: The Art \& Practice of the Learning Organization, New York: Doubleday Currency

Senge, P., Roberts, C., Ros, R.B., Smith, B.J., and Kliener, A. (1994). The Fifth Discipline Fieldbook: Strategies and Tools for Building a Learning Organization, New York: Doubleday Currency

Stemler, Steve (2001). An overview of content analysis. Practical Assessment, Research \& Evaluation, 7(17). Retrieved from http://PAREonline.net/getvn.asp?v=7\&n=17

Stephan. W and Stephan, C. W. (2001). Improving intergroup relations. Thousand Oaks, CA: Sage

Taylor, D.M., and Moghaddam, F.M. (1994). Theories of intergroup relations ( $2^{\text {nd }}$ ed.). Westport, Conn.: Praeger.

Tint, B.S. (2010). Dialogue, Forgiveness, and Reconciliation. In Ani Kalayjian and Raymond F. Paloutzian (Eds.), Forgiveness, and Reconciliation. Springer.

Tint, B. (2012).Diasporas in dialogue: A manual for dialogue, transition and community reconciliation. Portland, OR: Portland State University.

University of Michigan. (n.d.). Multi-University Intergroup DIaogue Research ProjectGuidebook. Available from http://sitemaker.umich.edu/migr/files/migr_guidebook.pdf 
Van Dijk, T. A. (1995). Aims of critical discourse analysis. Japanese discourse. 1. P. 1727

Wah, L.M. (2004). The art of minful facilitation. Stirfry Seminars \& Consulting. Berkeley, California.

Weber, R. P. (1990). Basic Content Analysis, 2nd ed. Newbury Park, CA.

Wayne, E. K. (2008). Is it just talk? Understanding and evaluating intergroup dialogue. Conflict resolution Quaterly. 25(4) p 451-477

Wilchins, R. (2002). Changing the Subject: Gender Queer. Los Angeles, Alyson Books.

Zúñiga, X., Nagda, B. A., \& Sevig, T. D. (2002). Intergroup dialogues: An educational model for cultivating engagement across differences. Equity and Excellence in Education, 35(1), 7-17.

Zuniga, X., Nagda, B.A, Chesler, M., and Cytron-Walker, A. (eds.) (2007). Intergroup dialogue in Higher Education: meaningful Learning about Social Justice. ASHEERIC Higher Education Report, 32(4) 
Appendices 


\section{Appendix A-Dialogue Invitation Flyer}

\section{OPPORTUNITY TO SHARE AND BE HEARD}

$>$ Do you feel hesitant to share your story on issues like race, identity, politics, and religion?

$>$ Are you afraid of hurting somebody's feeling when expressing your opinion on these issues?

$>$ Do you want to learn about dialogic conversation?

Interested? Come participate with us in this exciting 5 weeks of life changing event. So, what is a dialogue? It is neither a debate nor a discussion! It is a conversation in a safe and respectful space with appreciative inquiries sharing of stories, and practicing mindful listening skills. Additionally, it is an opportunity to develop understanding amid differences.

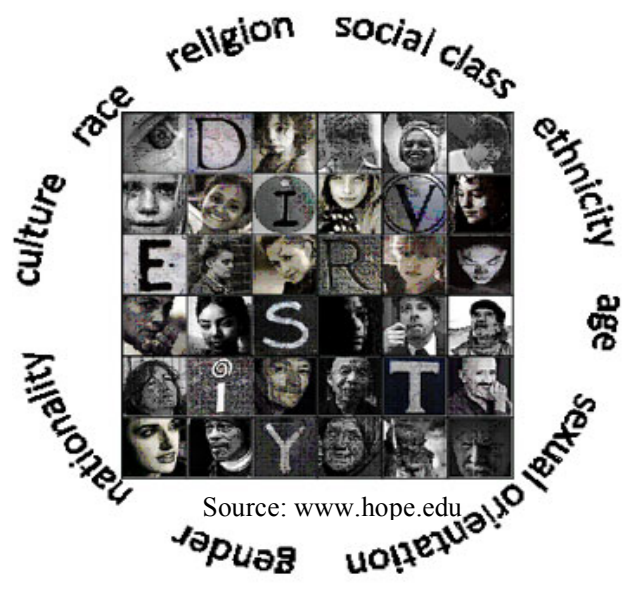

\section{Details}

Time: Every Thursday 2-4 pm. Starting from November 7 - December, 2013. Snacks will be provided. All participants will receive a certificate and gift upon completion of the series.

Venue: International Student Lounge, East Hall 121

Facilitators: Lisha Shrestha and Surya Raj Joshi are experienced workshop facilitators on issues of diversity, conflict resolution, art of listening, identity, and gender. Both have facilitated workshops with various refugee populations and students at Immigrants and Refugee Community Organization (IRCO) and Portland State University respectively. This is also culmination of their final thesis and project.

Co-Partners/supporters/sponsors: This event is being partnered with and supported by Conflict Resolution Graduate Program, International Student Life Office and Associated Students of PSU (ASPSU).

Objective: Apart from being thesis / project, this series will also be an important step in developing Intergroup Dialogue curriculum and academic resource on identity and diversity within the University. This will be useful in creating a safe space to have a dialogue within university communities to promote diversity and increases inter-cultural understanding. Also, the International Affairs committee within PSU student government will be using this curriculum later to conduct conversations between PSU students and other students around the world. Thus, we are hoping to expand PSU's views as well as create a global connection within universities to enrich the students' educational experiences as well as the universities services, making these institutions more culturally competent. 


\section{Appendix B-Pre-Dialogue Questionnaire}

\section{Pre-Dialogue Questionnaire}

\begin{tabular}{|lllll}
\hline ID Number: & & & Age: & \\
Gender: $\quad$ Male $\square$ & Female $\quad \square$ & Other $\square$ & Please Specify \\
Race/ Ethnicity: & & Religion: & \\
Major: & & & Year: \\
Level: Undergraduate $\square \quad$ Graduate $\square$ & Others $\square$ & Please Specify \\
& & & \\
\end{tabular}

1. Is intergroup dialogue new to you? Yes $\square \quad$ No $\square$

2. Why are you interested in participating in a dialogue?

3. Have you ever talked about race, ethnicity, religion or political belief in a mass or a larger forum?
Yes
No

If Yes, please specify,

4. What does identity means to you? 
5. How often do you identify yourself as a member of the following social identity groups? (Mark one for each item)

\begin{tabular}{|l|c|c|c|c|c|c|c|}
\hline $\begin{array}{c}\text { Social Identity } \\
\text { Groups }\end{array}$ & Never & Rarely & $\begin{array}{c}\text { Once in } \\
\text { a while }\end{array}$ & Sometimes & Often & $\begin{array}{c}\text { Almost } \\
\text { always }\end{array}$ & Always \\
\hline Race/Ethnicity & 1 & 2 & 3 & 4 & 5 & 6 & 7 \\
\hline Gender & 1 & 2 & 3 & 4 & 5 & 6 & 7 \\
\hline $\begin{array}{l}\text { Socio-economic } \\
\text { class }\end{array}$ & 1 & 2 & 3 & 4 & 5 & 6 & 7 \\
\hline National Origin & 1 & 2 & 3 & 4 & 5 & 6 & 7 \\
\hline Age & 1 & 2 & 3 & 4 & 5 & 6 & 7 \\
\hline Religion & 1 & 2 & 3 & 4 & 5 & 6 & 7 \\
\hline Sexual orientation & 1 & 2 & 3 & 4 & 5 & 6 & 7 \\
\hline Other (Specify) & 1 & 2 & 3 & 4 & 5 & 6 & 7 \\
\hline
\end{tabular}

6. How do you generally feel when interacting with people from social identity group different from your own? Look at the following options and place yourself in the continuum. (Mark one for each item)

\section{Ifeel}

$\begin{array}{llllllllll}1 & 2 & 3 & 4 & 5 & 6 & 7 & 8 & 9 & 10\end{array}$

a. Not at all trusting $\quad$ Extremely trusting

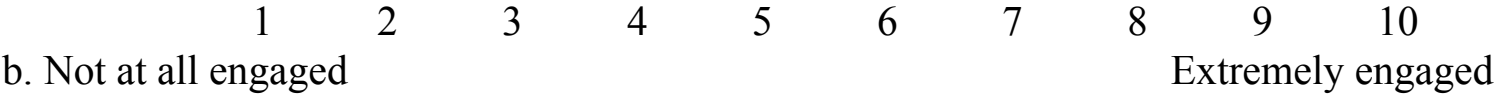

$\begin{array}{lllllllllll}1 & 2 & 3 & 4 & 5 & 6 & 7 & 8 & 9 & 10\end{array}$

c. Not at all open $\quad$ Extremely open

$\begin{array}{lllllllllll}1 & 2 & 3 & 4 & 5 & 6 & 7 & 8 & 9 & 10\end{array}$

d. Not at all anxious $\quad$ Extremely anxious

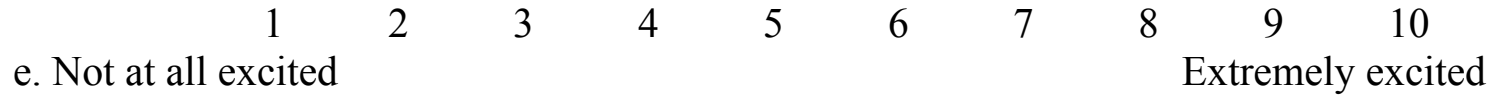

7. Have you ever-experienced conflict related with your identity? Yes

No 
8. What kind of identity conflict is more frequent in your life? (Mark one for each item)

\begin{tabular}{|l|c|c|c|c|c|c|c|}
\hline $\begin{array}{c}\text { Social Identity } \\
\text { Groups }\end{array}$ & Never & Rarely & $\begin{array}{c}\text { Once in } \\
\text { a while }\end{array}$ & Sometimes & Often & $\begin{array}{c}\text { Almost } \\
\text { always }\end{array}$ & Always \\
\hline Race/Ethnicity & 1 & 2 & 3 & 4 & 5 & 6 & 7 \\
\hline Gender & 1 & 2 & 3 & 4 & 5 & 6 & 7 \\
\hline $\begin{array}{l}\text { Socio-economic } \\
\text { class }\end{array}$ & 1 & 2 & 3 & 4 & 5 & 6 & 7 \\
\hline National Origin & 1 & 2 & 3 & 4 & 5 & 6 & 7 \\
\hline Age & 1 & 2 & 3 & 4 & 5 & 6 & 7 \\
\hline Religion & 1 & 2 & 3 & 4 & 5 & 6 & 7 \\
\hline Sexual orientation & 1 & 2 & 3 & 4 & 5 & 6 & 7 \\
\hline Other (Specify) & 1 & 2 & 3 & 4 & 5 & 6 & 7 \\
\hline
\end{tabular}

9. Can you share more about those conflicts?

10. Have you ever felt being misunderstood and discriminated because of your identity? :(Mark one for each item)

\begin{tabular}{|l|c|c|c|c|c|c|c|}
\hline $\begin{array}{c}\text { Social Identity } \\
\text { Groups }\end{array}$ & Never & Rarely & $\begin{array}{c}\text { Once in } \\
\text { a while }\end{array}$ & Sometimes & Often & $\begin{array}{c}\text { Almost } \\
\text { always }\end{array}$ & Always \\
\hline Race/Ethnicity & 1 & 2 & 3 & 4 & 5 & 6 & 7 \\
\hline Gender & 1 & 2 & 3 & 4 & 5 & 6 & 7 \\
\hline $\begin{array}{l}\text { Socio-economic } \\
\text { class }\end{array}$ & 1 & 2 & 3 & 4 & 5 & 6 & 7 \\
\hline National Origin & 1 & 2 & 3 & 4 & 5 & 6 & 7 \\
\hline Age & 1 & 2 & 3 & 4 & 5 & 6 & 7 \\
\hline Religion & 1 & 2 & 3 & 4 & 5 & 6 & 7 \\
\hline Sexual orientation & 1 & 2 & 3 & 4 & 5 & 6 & 7 \\
\hline Other (Specify) & 1 & 2 & 3 & 4 & 5 & 6 & 7 \\
\hline
\end{tabular}


11. Why do you think such misunderstanding and discrimination happens?

12. How have you dealt with such situation?

13. What was easy and difficult while dealing with situation?

Easy:

Difficult:

14. What are some major issues on identity would you like to see addressed in the dialogue sessions?

15. Anything you want to add that can be helpful for the session? 


\section{Appendix C-Post-Dialogue Questionnaire}

\section{Post-Dialogue Questionnaire}

ID Number:

Age:

Gender: Male $\square$ Female $\square \quad$ Other $\square \quad$ Please Specify

Race/ Ethnicity:

Economic Class (Optional): Low Class $\square \quad$ Middle Class

Upper Middle $\square \quad$ Upper Class

Major:

Year:

Level: Undergraduate Graduate Others Please Specify

1. How do you define your experience of participating in dialogue?

2. Do you feel the dialogue changed your perception toward identity?

Yes No

3. If yes, what changes have you noticed?

4. If no, please explain 
5. How your identity helped/ limited your participation in dialogue? (Explain all that applies)

Gender Identity

Racial Identity

Religious Identity

Language

Social Economic Identity

Age

6. What helped you to trust and share your story/experience in dialogue? 
7. How dialogue helped/not helped you to better resonate with other feelings? Explain. If helped:

If not helped:

8. How do you generally feel when interacting with people from social identity group different from your own? Look at the following options and place yourself in the continuum. (Mark one for each item)

\section{Ifeel}

\section{2}

a. Not at all trusting

$\begin{array}{llll}1 & 2 & 3 & 4\end{array}$

b. Not at all engaged

$\begin{array}{llll}1 & 2 & 3 & 4 \\ \text { c. Not at all open }\end{array}$

$\begin{array}{llll}1 & 2 & 3 & 4\end{array}$

d. Not at all anxious

$\begin{array}{llll}1 & 2 & 3 & 4\end{array}$

e. Not at all excited

5

6

5

$$
6
$$

7

89

5

6

7

8

9

$\begin{array}{lllll}5 & 6 & 7 & 8 & 9\end{array}$

56

7

8

9

10

Extremely trusting 10 Extremely engaged 10 Extremely open 10 Extremely anxious 10 Extremely excited

9. How do you think participating in dialogue helped you to better understand conflict related to identity issues (Gender, race, sexual orientation, national, age, religion)?

10. Do you think dialogue helped you to cope with situation of misunderstanding and mistreatment because of your identity?

$$
\text { Yes No }
$$

\section{Explain}


11. Has the sessions helped to meet your expectation of participating in a dialogue series? Yes No 


\section{Appendix D-Outline/content of each dialogue session}

\section{Intergroup dialogue: Session 1}

Place:

Date:

Time:

Facilitators:

Goals:

- Introduce participants

- Create Processed agreement (ground rules)

- Start dialogue process

- Ensure comfort for participants and create safe environment for dialogue.

\begin{tabular}{|c|c|c|}
\hline Topic & Method & Process \\
\hline $\begin{array}{l}\text { Welcome } \\
5 \text { minutes }\end{array}$ & Oral welcome message & $\begin{array}{l}\text { - Facilitator welcomes the participants } \\
\text { and talk about logistics. } \\
\text { - Group will play the name game. }\end{array}$ \\
\hline $\begin{array}{l}\text { Weaver form } \\
\text { signature } \\
10 \text { minutes } \\
\text { Development } \\
\text { of Process } \\
\text { agreement } \\
30 \text { minutes }\end{array}$ & $\begin{array}{l}\text { Participants sign the consent } \\
\text { form } \\
\text { Group participation and } \\
\text { Brainstorming } \\
\text { Materials } \\
\text { Sticky pad markers, flipchart }\end{array}$ & 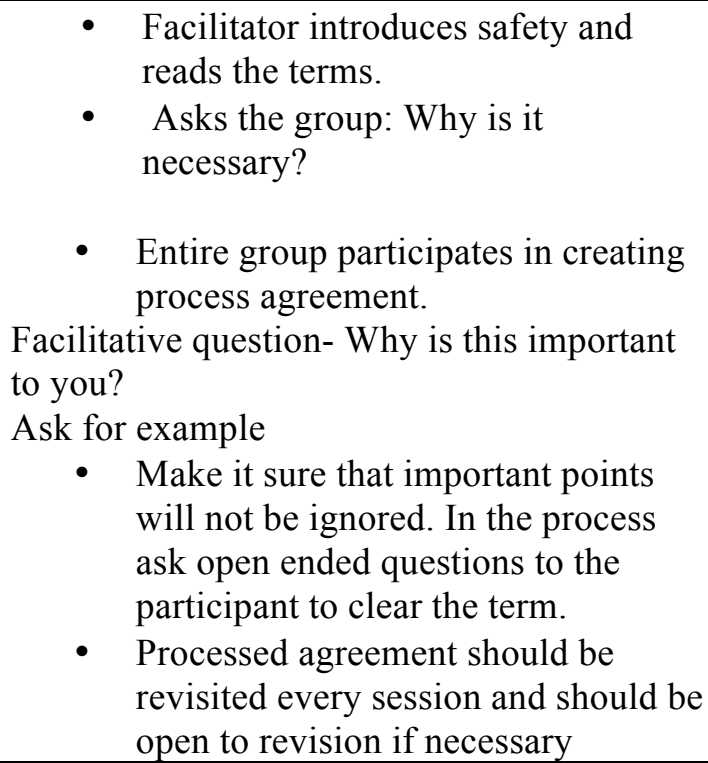 \\
\hline $\begin{array}{l}\text { Mindful } \\
\text { Listening/ } \\
\text { Observation } \\
\text { assumption } \\
15 \text { minutes }\end{array}$ & $\begin{array}{l}\text { In the group of four, do the } \\
\text { listening exercise } \\
\text { Materials } \\
\text { Sheets }\end{array}$ & $\begin{array}{l}\text { Look at each other and see your } \\
\text { observations and assumptions. Use } \\
\text { the provided sheet for note taking. } \\
\text { Reflect with each other }\end{array}$ \\
\hline \multicolumn{3}{|l|}{ Silence } \\
\hline $\begin{array}{l}\text { Dialogue } \\
50 \text { minutes }\end{array}$ & Go around & $\begin{array}{l}\text { Tell us about your identity. Start with the } \\
\text { impression from initial exercise. } \\
\text { GOALS } \\
\text { • Make everyone aware about their } \\
\text { and other participant's identity. }\end{array}$ \\
\hline
\end{tabular}




\begin{tabular}{|c|c|c|}
\hline & & $\begin{array}{l}\text { - Provide opportunity to share and } \\
\text { listen } \\
\text { - Establish connection in the group }\end{array}$ \\
\hline & Popcorn (Turn taking) & $\begin{array}{l}\text { Why is it important to you? Can you share a } \\
\text { story related to the issue? Prefer to have } \\
\text { some example from participants. } \\
\text { Goals: } \\
\text { - To have a concrete example on } \\
\text { importance of identity. } \\
\text { - Identify shared experience, emotions, }\end{array}$ \\
\hline $\begin{array}{l}\text { Closing } \\
10 \text { minutes }\end{array}$ & Popcorn (Take turn ) & $\begin{array}{l}\text { How does it feel to have the ability to express } \\
\text { and listened to? } \\
\text { Is this conversation different to what we } \\
\text { usually have? }\end{array}$ \\
\hline
\end{tabular}

Notes:

If sudden emotions come, ask group members to reflect and acknowledge it. Let the group validate emotions.

Occasionally remind the process agreement if it seems not getting followed.

After the second question, inquire about moments when strong reaction comes, involve the group to acknowledge and validate such incidents. 


\section{Intergroup dialogue: Session 2}

Place:

Date:

Time:

Facilitators:

Goals:

- Continue dialogue process.

- Make participant comfortable for dialogic conversation and create safe environment for dialogue.

\begin{tabular}{|c|c|c|}
\hline Topic & Method & Process \\
\hline $\begin{array}{l}\text { Welcome } \\
5 \text { minutes }\end{array}$ & Oral welcome message & $\begin{array}{l}\text { - } \quad \text { Facilitator lead the process of } \\
\text { welcoming the participants and talk } \\
\text { about logistics. } \\
\text { - } \quad \text { Group will replay the name game. }\end{array}$ \\
\hline $\begin{array}{l}\text { Review of } \\
\text { processed } \\
\text { agreement } \\
20 \text { minutes }\end{array}$ & $\begin{array}{l}\text { Group participation and } \\
\text { Brainstorming }\end{array}$ & $\begin{array}{l}\text { - A quick revision by the group/ read } \\
\text { each. } \\
\text { Make sure if the participants want to } \\
\text { add anything to the processed } \\
\text { agreement based on their experience } \\
\text { of previous session. }\end{array}$ \\
\hline $\begin{array}{l}\text { Play pointing } \\
\text { game } \\
5 \text { minutes }\end{array}$ & $\begin{array}{l}\text { A participant will point } \\
\text { towards other participant } \\
\text { and agrees to move } \\
\text { without speaking. When } \\
\text { the first person starts } \\
\text { walking the other person } \\
\text { have to do the same and } \\
\text { secure a space and thus the } \\
\text { sequence continues. }\end{array}$ & $\begin{array}{l}\text { A facilitator explains the process and } \\
\text { demonstrates with co facilitator if available. }\end{array}$ \\
\hline $\begin{array}{l}\text { Fear in the Hat } \\
15 \text { minutes }\end{array}$ & $\begin{array}{l}\text { Write down the fear in a } \\
\text { slip of paper put it in a } \\
\text { box. Each person will pick } \\
\text { and read one. }\end{array}$ & \\
\hline $\begin{array}{l}\text { Dialogue } \\
1 \text { hour } 25 \\
\text { minutes }\end{array}$ & Go around & $\begin{array}{l}\text { Reflect from the two games } \\
\text { Summarize the main theme that came the } \\
\text { previous session so that participants will } \\
\text { be able to take off from there. } \\
\text { From last week everyone had a definition of } \\
\text { identity? Does that stimulate some thought } \\
\text { over the week's time? Any conversation? }\end{array}$ \\
\hline
\end{tabular}




\begin{tabular}{|c|c|c|}
\hline & & $\begin{array}{l}\text { Any self reflection? } \\
\text { GOALS } \\
\begin{array}{l}\text { - Make everyone aware about their } \\
\text { and other participant's identity. } \\
\text { Provide opportunity to share and } \\
\text { listen } \\
\text { - Establish connection in the group }\end{array}\end{array}$ \\
\hline & Popcorn (Turn taking) & $\begin{array}{l}\text { Why is it important to you? Can you share a } \\
\text { story related to your identity? Prefer to have } \\
\text { some example from participants. } \\
\text { Goals: } \\
\text { - To have a concrete example on } \\
\text { importance of identity. } \\
\text { - Identify shared experience, emotions } \\
\text { let the group take time to think about } \\
\text { it }\end{array}$ \\
\hline $\begin{array}{l}\text { Closing } \\
10 \text { minutes }\end{array}$ & Popcorn (Take turn ) & $\begin{array}{l}\text { How does it feel to have the ability to speak } \\
\text { and listen? } \\
\text { Is this conversation different to what we } \\
\text { usually have? }\end{array}$ \\
\hline
\end{tabular}

It is important to start from there the group left last session. Facilitator should note the important moment, theme or words that had highest impact each session so that could be used during next session to ensure smooth transition to different themes.

If it could be observed, participants should be made aware of the stages of dialogue so as to ensure their understanding of dialogic process.

If sudden emotions come, ask group members to reflect and acknowledge it. Let the group validate emotions.

Occasionally remind the process agreement if it seems not getting followed After the second question, inquire about moments when strong reaction comes, involve the group to acknowledge and validate such incidents. 


\section{Intergroup dialogue: Session 3}

Place:

Time:

Goals:
Date:

Facilitators:

- Revisit some of the interesting moments of past session

- Dig deeper into the core idea of self identity and its connection with society.

\begin{tabular}{|c|c|c|}
\hline Topic & Method & Process \\
\hline $\begin{array}{l}\text { Welcome } \\
5 \text { minutes }\end{array}$ & Oral welcome message & $\begin{array}{l}\text { - Facilitator welcomes the participants and } \\
\text { talk about logistics. } \\
\text { - Group will play the name game. }\end{array}$ \\
\hline $\begin{array}{l}\text { Reflection } \\
\text { of past } \\
\text { session } \\
25 \text { minutes } \\
\text { Value } \\
\text { development } \\
1 \text { hour } 20 \\
\text { minutes }\end{array}$ & $\begin{array}{l}\text { Facilitator revisits some } \\
\text { important moment/ } \\
\text { comments of past session } \\
\text { Facilitative inquiry }\end{array}$ & $\begin{array}{l}\text { Statement of the comments from } \\
\text { participants and validation } \\
\text { Make the group aware of any pattern/ } \\
\text { that is emerging and have the group's } \\
\text { opinion on it. } \\
\text { - Participants randomly express } \\
\text { their impression on values and } \\
\text { how they are influenced. } \\
\text { Goals: Indulge in deeper understanding of value } \\
\text { - formulation. } \\
\text { - Individual and group value formation and } \\
\text { possible exploration of how values can } \\
\text { differ. }\end{array}$ \\
\hline $\begin{array}{l}\text { Closing } \\
10 \text { minutes }\end{array}$ & Go around the circle & $\begin{array}{l}\text { How does it feel to have the ability to express and } \\
\text { listened to? } \\
\text { Is this conversation different to what we usually } \\
\text { have? }\end{array}$ \\
\hline
\end{tabular}




\section{Intergroup dialogue: Session 4}

Place:

Time:

Goals:
Date:

Facilitators:

- Revisit some of the interesting moments of past session

- Dig deeper into the core idea of self identity and its connection with society.

- Have dialogue about stereotype.

\begin{tabular}{|c|c|c|}
\hline Topic & Method & Process \\
\hline $\begin{array}{l}\text { Welcome } \\
5 \text { minutes }\end{array}$ & Oral welcome message & $\begin{array}{l}\text { Facilitator welcomes the participants } \\
\text { and talk about logistics. } \\
\text { - Group will play the name game. }\end{array}$ \\
\hline $\begin{array}{l}\text { Reflection of } \\
\text { past session } \\
25 \text { minutes } \\
\text { Value } \\
\text { development } \\
1 \text { hour } 20 \\
\text { minutes }\end{array}$ & $\begin{array}{l}\text { Facilitator revisits some } \\
\text { important moment/ } \\
\text { comments of past session } \\
\text { Facilitative inquiry }\end{array}$ & $\begin{array}{l}\text { - Statement of the comments from } \\
\text { participants and validation } \\
\text { Facilitator summarizes emerging } \\
\text { theme from previous session and how } \\
\text { some of the discussion was related to } \\
\text { stereotyping. } \\
\text { - Participants randomly express their } \\
\text { impression on values and how they are } \\
\text { influenced. } \\
\text { - Continue the dialogue from where the } \\
\text { group left last week } \\
\text { - How have your values developed? } \\
\text { Dialogue Prompts: } \\
\text { - How does value affect stereotypes? } \\
\text { Have you been stereotyped? } \\
\text { Have you assumed something about } \\
\text { other people before they had chance to } \\
\text { clear them? } \\
\text { How do you think you have thought } \\
\text { about victim/ perpetrator role in } \\
\text { stereotyping? } \\
\text { Goals: } \\
\text { Develop understanding about origin } \\
\text { and effect of stereotypes. } \\
\text { Make the group aware that how } \\
\text { unknowingly these concepts are } \\
\text { affecting us. }\end{array}$ \\
\hline
\end{tabular}




\begin{tabular}{|l|l|l|}
\hline $\begin{array}{l}\text { Closing } 10 \text { minutes } \\
1 \text { Go around the circle }\end{array}$ & $\begin{array}{l}\text { How does it feel to have the ability to express and } \\
\text { listened to? Is this conversation different to what we } \\
\text { usually have? }\end{array}$ \\
\hline
\end{tabular}




\section{Intergroup dialogue: Session 5}

Place:

Time: 2
Date:

Facilitators:

Goals:

- Invite participants to revisit some of the changes they have experienced.

- Identify important accomplishment of the dialogue.

- Empower participants to navigate ways ahead

- Ensure the skills gained in dialogue and the understanding of dialogic way of communication will be used ahead in participant's life.

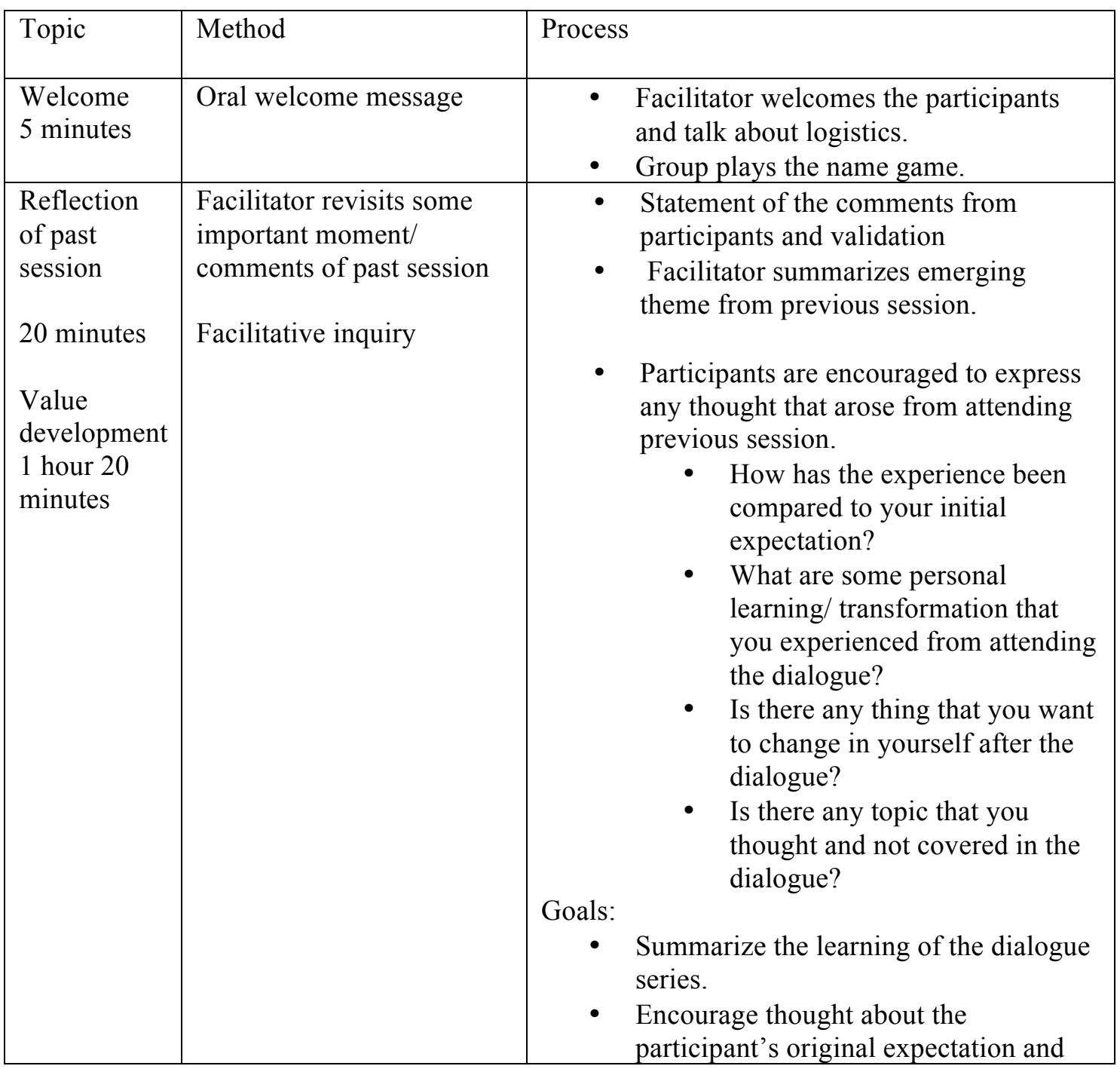




\begin{tabular}{|l|l|l|}
\hline \multirow{1}{*}{} & & $\begin{array}{l}\text { end result. } \\
\text { Evoke enthusiasm on any unfinished } \\
\text { topic so as to encourage participant to } \\
\text { have more exploration of the burning } \\
\text { issues in their mind. }\end{array}$ \\
$\begin{array}{l}\text { Ensure that group process does not end } \\
\text { with the dialogue but can be continued } \\
\text { and integrated in the works and } \\
\text { communication people have in their } \\
\text { ordinary life. }\end{array}$ \\
\hline 15 minutes & Go around the circle & $\begin{array}{l}\text { How does it feel to have the ability to express } \\
\text { and listened to? } \\
\text { Is this conversation different to what we usually } \\
\text { have? }\end{array}$ \\
& & \\
\hline
\end{tabular}




\section{Appendix E - Common Group Guidelines (Processed Agreements)}

- One mike: Take turn when speaking; Do not speak when other person is speaking.

- Speak for yourself.

- Respect confidentiality of the other participants.

- Be on time.

- Electronics on silent mode.

- Take care of each other in the difficult moment.

- Listen carefully to what others have to say.

- Acknowledge other participant's stories.

- Give a chance for silent voice to come out.

- Do not ask offensive questions.

- Accept responsibility for your thought and feelings. 
Appendix F-Evaluation of dialogue

Dialogue Evaluation

How do you rate the dialogue in the scale of 1-7.

\begin{tabular}{|c|c|c|c|c|c|c|}
\hline $\mathbf{1}$ & $\mathbf{2}$ & $\mathbf{3}$ & $\mathbf{4}$ & $\mathbf{5}$ & $\mathbf{6}$ & $\mathbf{7}$ \\
\hline \multicolumn{2}{|c|}{ Bad } & \multicolumn{2}{|c|}{ Okay } & Pretty Good & \multicolumn{2}{c|}{ Very good } \\
\hline
\end{tabular}

What did you like / find valuable about the dialogue?

What did not like/find valuable about this course?

What would you change, add or delete from the dialogue?

How helpful was the facilitation during the dialogue?

Would you recommend dialogue like this to other people? Why/ why not?

Additional Comments? Suggestions? 


\section{Appendix G-List of activities used in dialogue process}

List of activities

Activity 1: Fear in the hat:

Materials needed:

- Question s priented in the piece of paper, cut and folded.

- Hat or a basket.

- Seats

Questions for Fear in the hat exercise:

- I speak more than one language.

- I have experienced different treatment because of my identity (Race/ religion/ ethnicity/gender....)

- I have not interacted in my class because of my limited proficiency in the language of instruction.

- I remember at least one instance, where I was hurt because of my identity.

- There are some department/ offices in university where I don't like to go because I feel mistreated/ unsafe/ unwelcomed because of my identity.

- I have at least once taken advantage of my identity (Race/ gender/ national origin/ religion....etc)

- There are certain groups either in campus/ my office/ my community which I try to avoid because of difference in our (Race/ gender/ national origin/ culture/ ethnicity...)

- In a new setting I tend to explain more about my national/ cultural /gender/ racial/ religious identity to make myself feel heard recognized and empowered.

Instruction:

- In the middle of circle piece of folded paper with questions are put in a hat.

- One of the seats is removed so that one person is standing in the middle while other people are sitting.

- The participant in the middle picks one paper and reads the question.

- Participants who have experienced the situation described in the statement change the seats along with the reader.

- The participant who does not get to seat comes to middle and repeat the process.

- The process is repeated until all the statements are read.

Activity 2: Power:

Materials needed:

1 deck of card

Instructions:

Part one: 
- Distribute the random cards from the deck to each participants.

- Participants are not allowed to see their card.

- Participants hold the card in their head so that everybode else see what card it is.

- Participants behave to the other participants as the hierarchy of the card. For example Aces gets the most respect while 2 gets least or no respect.

- Continue the activity of meeting and greeting according to the hierarchy.

Part 2:

- The cards are again distributed randomly.

- Person getting the card can only see his/her card.

- Participants repeat the same thing as above. Only difference this time is that no one is aware of the hierarchy. Everybody knows their own position while being not aware about other's.

- Continue the meet and greet for about 2 minutes.

- Sit back and reflect.

Activity 3: Observation- Assumption:

Materials needed:

Bblank sheets of paper

Instructions:

- Participants are paired in groups of two. They are encouraged to select the one who they do not know as their pair.

- A blank sheet with observation written in top left and assumption written in top right is distributed to each participant.

- Then participants are asked to look at the appearance of each other. Appearance can be dress, hair style, body posture, the way they speak and accent, way they smile, way their hair is done or whatever the observe can notice.

- Note each observation in the observation side of the sheet.

- On the Assumption side, write what you assumed from the observations. Some observation may not have assumptions

- Participants discuss the observation and assumptions with their partners.

- Group convenes back and reflects to the exercise. Before groups convene back, participants should take permission from their partners if they want some/ or any of the observations/ assumptions to be shared to the group. 


\title{
Appendix H-Consent form
}

\author{
Portland State University \\ Conflict Resolution Graduate Program \\ Adult Consent
}

\begin{abstract}
Name of Research/ Project: Exploring Issues of Conflict through Intergroup Dialogue Faculty Supervisor: Prof. Barbara Tint Researcher: Lisha Shrestha

You are invited to participate in a research study conducted by Lisha Shrestha from Portland State University, Conflict Resolution Graduate Program. The researcher hopes to explore issues of conflict through intergroup dialogue. This study is being conducted as a requirement for master's degree of Lisha Shrestha. Prof. Dr. Barbara Tint is the supervisor of the project. You were selected as a possible participant because of your experience as a student from distinct cultural, racial and national background.
\end{abstract}

If you decide to participate, you will be asked to attend 5-dialogue sessions held in focus group format. There will be one two hour session each week and an information session. You will be asked to fill pre and post dialogue questionnaires. You will receive a certificate upon completion of the session. You may not receive any direct benefit from taking part in this study, but the study may help to increase knowledge, which may help others students in the future.

As part of the study, video/audio recording will be done in some part of the dialogue session. These recordings are only used for the purpose of this research writing and will never be used for public broadcasting or any other purpose. Any information that is obtained in connection with this study and that can be linked to you or identify you will be kept confidential. Additionally, the identifying elements will be separated from the data to ensure greater protection of identity of the participants. This information will be kept confidential by keeping them securely in a file at Conflict Resolution Department. The file will be kept in a secure locker, the keys of which will be only available to department administrator. The digital copies of any documents that can be used to identify the subjects will be kept securely in $\mathrm{H}$ : drive behind password protection. The data will be kept as per federal guidelines for a period of three years after which they will be deleted and securely shredded. The data will never be transported away from PSU.

The investigator and research staff must report any information that leads them to suspect the risk of harm or abuse to the subject (participant) him/herself or minors, or the elderly. In such a situation, the subject's confidentiality cannot be assured.

The following are the risk involved from participation in the research and research teams safeguards to avert them. 


\begin{tabular}{|c|c|}
\hline Risks & Safeguards \\
\hline $\begin{array}{l}\text { Intense emotional moments can affect } \\
\text { the dialogue process }\end{array}$ & $\begin{array}{l}\text { Safe space will be created to trust and } \\
\text { respect each other's feelings. } \\
\text { Processed agreement (Ground Rule) } \\
\text { will be discussed before the actual } \\
\text { dialogue to create a safe space. Deep } \\
\text { inquiries and reflection will be done to } \\
\text { validate emotions and normalize } \\
\text { intense situations. }\end{array}$ \\
\hline $\begin{array}{l}\text { Discomfort and Embarrassment to the } \\
\text { interviewees, if their identity is } \\
\text { exposed in the final curriculum }\end{array}$ & $\begin{array}{l}\text { Individual identities will never be } \\
\text { exposed in any publications. Video } \\
\text { recorded will be used only for } \\
\text { observation and taking reference for } \\
\text { research. Video/audio recorded will } \\
\text { never be shown in public media. } \\
\text { Utmost care will be taken to ensure } \\
\text { any unwanted data leaks. The hard } \\
\text { copy of transcript, and the digital data } \\
\text { collected from research will be kept in } \\
\text { secure location behind locker and } \\
\text { password protection and will be kept } \\
\text { and destroyed as per federal } \\
\text { guidelines. }\end{array}$ \\
\hline Risk of breach of confidentiality & $\begin{array}{l}\text { The participants are encouraged not to } \\
\text { speak of the discussions shared } \\
\text { outside of the research sessions. A } \\
\text { processed agreement (Ground Rules) } \\
\text { with group's participants will be made } \\
\text { before the dialogue to ensure } \\
\text { confidentialities. However, it is } \\
\text { stressed that confidentiality in the } \\
\text { sessions is not assured. }\end{array}$ \\
\hline
\end{tabular}

Your participation is voluntary. You do not have to take part in this study, and it will not affect your relationship with Conflict Resolution Graduate Program. You may also withdraw from this study at any time without affecting your relationship with Conflict Resolution Graduate Program.

If you have questions or concerns about your participation in this study, contact Dr. Barbara Tint at Conflict Resolution Graduate Program 503-725-9175. If you have concerns about your rights as a research subject, please contact Office of Research Integrity, 1600 SW 4th Ave., Market Center Building, Ste. 620, Portland, OR 97207; phone (503) 725-2227. 
Your signature indicates that you have read and understand the above information and agree to take part in this study. The researcher should provide you with a copy of this form for your own records.

\section{Signature Date}

Print name 